\title{
Design, Synthesis and Evaluation of Antiestrogen and Histone Deacetylase Inhibitor Molecular Hybrids
}

Rodrigo Mendoza-Sanchez ${ }^{\mathrm{a}}$, David Cotnoir-White ${ }^{\mathrm{b}}$, Justyna Kulpa ${ }^{\mathrm{b}}$, Isabel Jutras ${ }^{\mathrm{b}}$, Joshua Pottel ${ }^{\mathrm{a}}$, Nicolas Moitessier $^{\mathrm{a}}$, Sylvie Mader ${ }^{\mathrm{b}, *}$ and James L. Gleason ${ }^{\mathrm{a},{ }^{*}}$

${ }^{a}$ Department of Chemistry, Otto Maass Building, McGill University, 801 Sherbrooke Street West, Montreal, Québec, Canada, H3A OB8

${ }^{b}$ Institute for Research in Immunology and Cancer, Pavillon Marcelle-Coutu, Université de Montréal, 2950 chemin de Polytechnique, Montréal, Québec, Canada, H3T 1J4

\begin{abstract}
The combination of antiestrogens and histone deacetylase inhibitors (HDACi) has been found to be antiproliferative in breast cancer models. We designed and synthesized hybrid structures which combined structural features of the pure antiestrogen ICI-164,384 and HDACi's SAHA and entinostat in a single bifunctional molecule. The hybrids retained antiestrogenic and HDACi activity and, in the case of benzamide hybrids, were selective for Class I HDAC3 over Class II HDAC6. The hybrids possessed low micromolar to high nanomolar activity against both ER+ MCF-7 and ER-MDA-MB-231 breast cancer cell models.
\end{abstract}

\section{Introduction.}

Breast cancer is the most common form of neoplasia in women in the Western world and second cause of mortality after lung cancer. ${ }^{1}$ Estrogens, mainly $17 \beta$-estradiol $\left(E_{2}, \mathbf{1}\right.$, Figure 1$)$, play a crucial role in the development of female secondary sexual characteristics including normal breast growth. ${ }^{2}$ Estrogen signaling is mediated by intracellular estrogen receptors (ER $\alpha$ and $E R \beta)$, members of the nuclear receptor superfamily that regulate gene expression through binding to DNA response elements associated within target genes. ${ }^{3}$ While ER $\alpha$ is expressed at low levels in normal tissues, it is overexpressed in about $67 \%$ of hormone-dependent tumors, which represent $75 \%$ of breast cancers. ${ }^{4}$ Estrogenic stimulation of ER $\alpha$ is a major contributor of mammary tumorigenesis and is thus an important target in the treatment of breast cancer. ${ }^{5}$

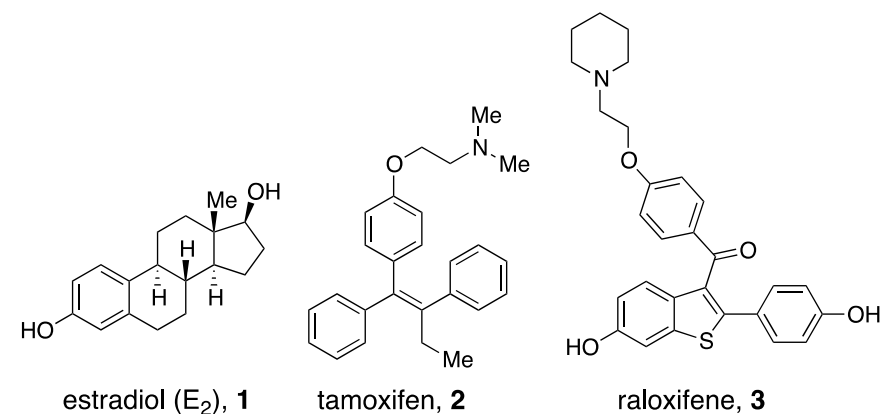

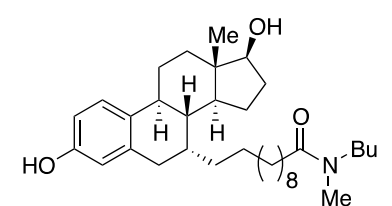

ICl-164,384, 4

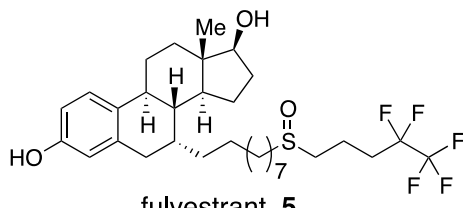

fulvestrant, $\mathbf{5}$

Figure 1. Structures of estrogens and antiestrogens

Two classes of competitive ER inhibitors have been developed for breast cancer treatment, selective estrogen receptor modulators (SERMs), ${ }^{6}$ exemplified by tamoxifen $(\mathbf{2})^{7}$ and raloxifene $(\mathbf{3}),{ }^{8}$ and pure antiestrogens, which act as selective estrogen receptor downregulators (SERDs), ${ }^{9}$ exemplified by ICI$164,384(\mathbf{4})^{9 \mathrm{~b}}$ and fulvestrant (ICI-182,780, 5). ${ }^{10}$ SERMs display partial agonist activity in a tissue- and genespecific manner. ${ }^{11}$ For instance, tamoxifen is an antagonist in breast cancer cells but has estrogenic effects on the uterus and bone mass, while raloxifene has less uterotrophic activity but retains agonist activity in bone. ${ }^{12}$ In contrast, pure antiestrogens like fulvestrant are antagonists in all tissues. In addition, fulvestrant induces ubiquitination and degradation of ER $\alpha$ via the proteasome pathway. ${ }^{13}$ Our recent studies showed that induction of ER SUMOylation also correlates with full antiestrogenicity. ${ }^{13 \mathrm{c}}$ SERMs are used as first-line therapy with about 50\% response rate overall (21-33\% in patients with metastatic disease). ${ }^{14}$ Fulvestrant is used mainly in second line treatment after progression on prior hormonal therapy, with an objective response 
rate evaluated at $7.4 \%$ in the EFECT trial. ${ }^{15}$ While these drugs have revolutionized breast cancer treatment, there is still a need for improved therapies.

Histone deacetylases (HDACs) and histone acetyltransferases (HATs) regulate the acetylation pattern of histones and non-histone proteins. ${ }^{16}$ In normal cells HDACs and HATs play an important role as transcriptional regulators by controlling compaction of DNA in the nucleosome. Aberrant expression of these enzymes has been observed in different cancer cell lines, including breast cancer. ${ }^{17}$ In recent years, histone deacetylase inhibitors (HDACi's) have emerged as potential therapeutic agents for the treatment of cancer. ${ }^{18}$ Preclinical studies of HDACi's have indicated roles in the regulation of differentiation, gene expression, cell cycle arrest, inhibition of proliferation and the promotion of apoptosis in a variety of cancer cell lines, including breast cancer cells. ${ }^{19}$ Currently, four HDAC inhibitors have been approved by the FDA, SAHA (6, Figure 2) and romidepsin (9) for cutaneous T-cell lymphoma, belinostat $(\mathbf{8})$ and romidepsin $(\mathbf{9})$ for peripheral T-cell lymphoma, and panobinostat (7) for the treatment of multiple myeloma. Other HDACi's such as entinostat (MS-275, 10) are in clinical trials. ${ }^{20}$
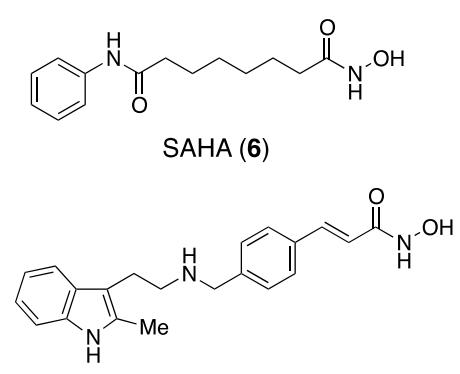

panobinostat (7)
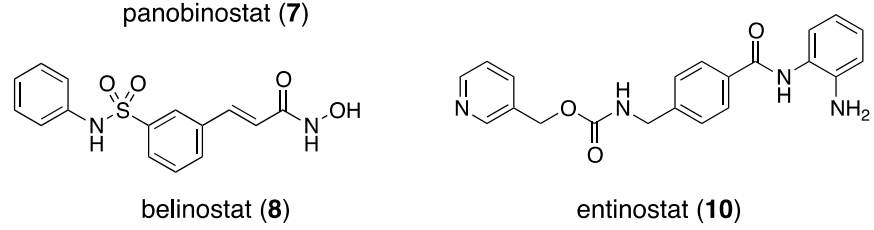

Figure 2. Structures of histone deacetylase inhibitors

HDACi's have shown promise in combination with other anti-cancer agents to improve treatment of solid tumors and also to combat development of resistance to these agents. ${ }^{21}$ Tamoxifen was found to cooperate with different HDACi's for suppression of ER+ breast cancer cell proliferation. ${ }^{22}$ A separate study showed that the combination of SAHA and fulvestrant was more potent in regulating the expression of cell cycle proteins, inducing downregulation of $\mathrm{ER} \alpha$, and decreasing the transcription of ER $\alpha$ targets in MCF-7 cells than fulvestrant alone. ${ }^{23}$ Subsequently, a phase II study of SAHA with tamoxifen in patients with ER-positive tumors progressing on endocrine therapy indicated a $19 \%$ objective response rate and a $40 \%$ clinical benefit rate. $^{24}$

Although combination therapy is the most common method for taking advantage of synergistic or additive effects between two drugs, ${ }^{25}$ our group and others have explored the concept of hybrid drugs, agents that combine two activities in a single molecule. ${ }^{26}$ Our group pioneered the incorporation of an HDACi pharmacophore into a nuclear receptor ligand. ${ }^{27}$ We developed triciferol, a hybrid molecule that possesses agonism for the vitamin D receptor and HDACi activity and shows enhanced cytostatic and cytotoxic activity against a number of cancer cell lines. We subsequently designed a wide variety of similar hybrids, based on both secosteroidal and non-secosteroidal cores. ${ }^{28}$ Subsequently, other groups have reported hybrids combining HDACi activity with inhibitory activity for EGFR/Her2, PI3K, and Ab1/PDBFRb/c-Kit kinases. ${ }^{29}$ Recently, three groups have shown that it is possible to combine HDACi activity into the side-chains of SERMs. ${ }^{30}$ Here we describe novel bi-functional SERD/HDACi hybrids based on the ICI-164,384 and fulvestrant structures as potential therapeutic molecules for breast cancer.

\section{Results and Discussion}

Design and synthesis. Significant structural overlap between HDACi's and estradiol-based pure antiestrogens suggested that the preparation of bifunctional hybrid molecules would be feasible. Pure antiestrogens generally possess a long alkyl chain attached to the core of estradiol at either the $7 \alpha$ or $11 \beta$ positions. ${ }^{9 \mathrm{~b}}$ In the structure of ICI-164,384 (4), the side chain attached at position $7 \alpha$ is an eleven carbon aliphatic chain terminating in a tertiary amide. This side chain disrupts the normal folding of ER helix 12 over the ligand binding pocket, a requirement for recruitment of transcriptional co-activators through LXXLL motifs. ${ }^{31}$ Structural studies on HDACi's bound to HDACs have identified a canonical pharmacophore comprised of three distinct motifs: ${ }^{32}$ a) a zinc binding group (ZBG), commonly a hydroxamic acid or 
benzamide, required for chelation to the zinc ion in the active site, b) a hydrophobic linker that occupies a hydrophobic tunnel connecting the active site to the surface, and c) a bulky, generally aromatic, cap group that interacts with the surface of the enzyme. In designing hybrids, we envisioned the estradiol core functioning as both a binding motif for the ER $\alpha$ ligand-binding pocket and a cap group for HDACi function. The side chain of ICI-164,384 could serve both as an antiestrogenic structural element as well as the linker in an HDACi. Finally, the tertiary amide of ICI-164,384 might be replaced with a hydroxamic acid (e.g. 11, Figure 3), N-butyl-hydroxamate or ortho-amino-anilide to impart the necessary zinc-binding activity of an HDACi.
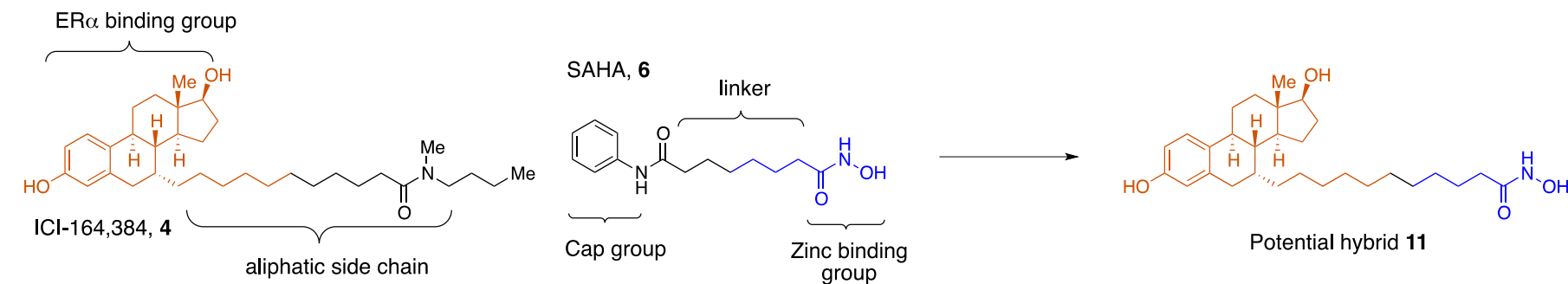

Figure 3. Pharmacophores of pure antiestrogen ICI-164384 and SAHA and their combination into a potential hybrid molecule.

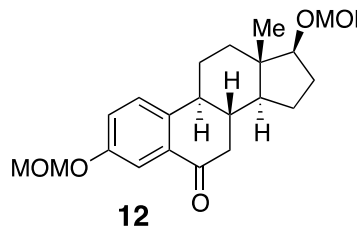

12

18

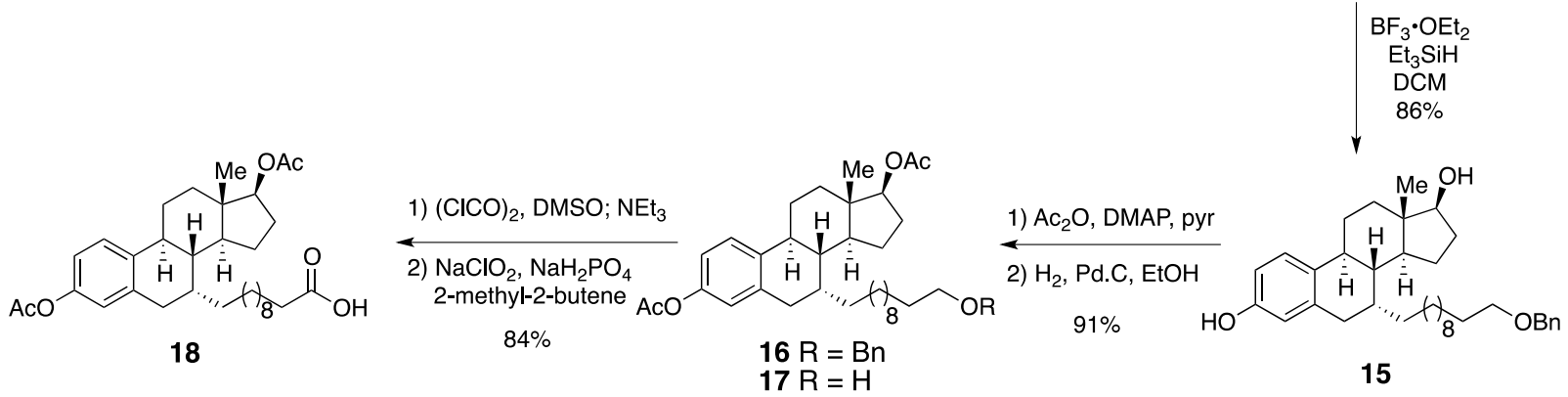

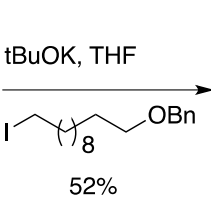

$52 \%$

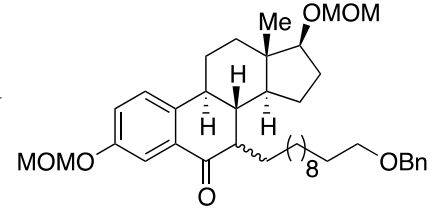

13

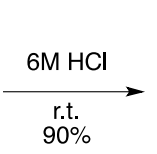<smiles>CC1(O)CCC2C(CC=CCOCc3ccccc31)C1CC(=O)c3cc(O)ccc3C21</smiles>

14

Scheme 1. Synthesis of common precursor 18

The synthesis of our first three hybrids was modeled on the work of Zhu et al. ${ }^{33}$ using bis-MOM-protected 6-oxoestradiol (12), available in three steps from estradiol, as a starting point to prepare carboxylic acid 18 as a common intermediate (Scheme 1). Alkylation of $\mathbf{1 2}$ by treatment with ${ }^{\mathrm{t}} \mathrm{BuOK}$ and 1-benzyloxy-11iodoundecane, afforded $\mathbf{1 3}$ in 52\% yield as a single stereoisomer after removal of minor amounts of the $\beta$ isomer and $\mathrm{O}$-alkylation products. Treatment of $\mathbf{1 3}$ with concentrated acid removed the MOM groups, affording 14 in $95 \%$ yield. Ionic reduction of the benzylic ketone was carried out with $\mathrm{Et}_{3} \mathrm{SiH}_{\mathrm{H} d ~} \mathrm{BF}_{3} \cdot \mathrm{OEt}_{2}$, providing diol $\mathbf{1 5}$ in $90 \%$ yield. After protection of $\mathbf{1 5}$ as a diacetate, hydrogenolysis of the benzyl group followed by oxidation of the resulting primary alcohol to the carboxylic acid in a two-step fashion (Swern/Pinnick) completed the synthesis of carboxylic acid 18 in 31\% yield from $\mathbf{1 2}$. 

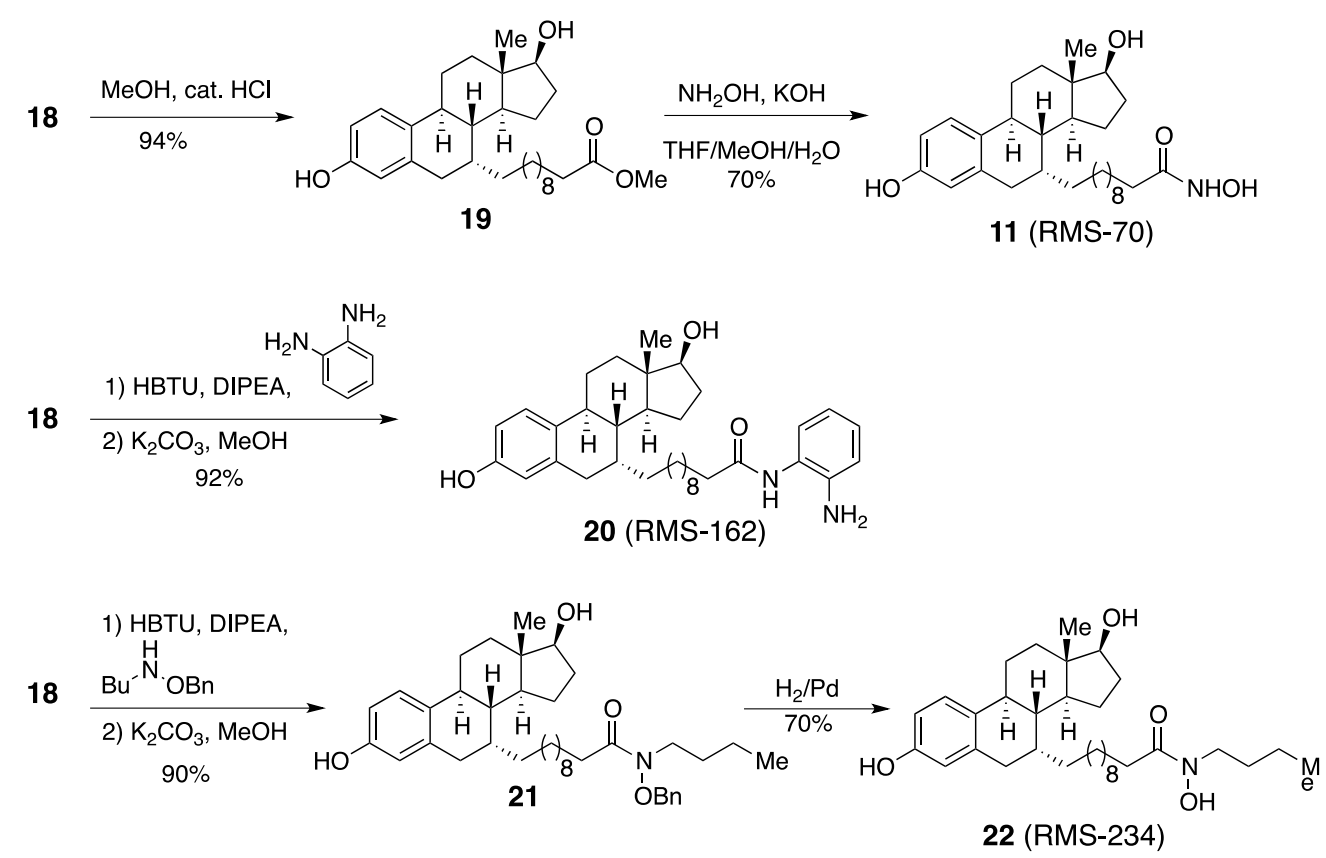

Scheme 2. Synthesis of hybrids RMS-70 (9), RMS-162 (20) and RMS-234 (22)

Carboxylic acid 18 served as a common intermediate for hybrids RMS-70 (11), RMS-162 (20) and RMS234 (22) (Scheme 2). Treatment of 18 with acidic methanol simultaneously cleaved the acetyl groups and esterified the carboxylic acid, and the resulting methyl ester 19 was directly transformed to the corresponding hydroxamic acid by treatment with hydroxylamine under basic conditions to give RMS-70 (11) in 66\% yield over two steps. Alternatively, carboxylic acid 18 was coupled with 2-aminoaniline using HBTU/DIPEA followed by treatment with $\mathrm{K}_{2} \mathrm{CO}_{3}$ in methanol to cleave the acetyl groups to provide RMS-162 (20) in $92 \%$ yield. Finally, $\mathbf{1 8}$ was coupled with $N$-butyl- $O$-benzylhydroxylamine using HBTU/DIPEA conditions followed by sequential deprotection of the acetyl and benzyl groups with $\mathrm{K}_{2} \mathrm{CO}_{3} /$ methanol and $\mathrm{H}_{2} / \mathrm{Pd}-\mathrm{C}$ to give RMS-234 (22) in $63 \%$ yield over three steps.

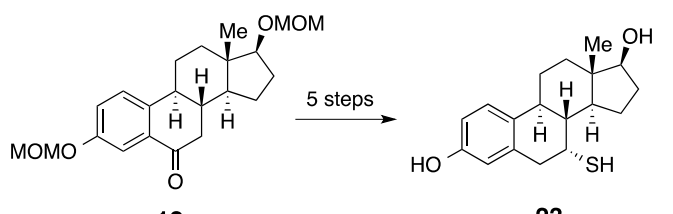

23

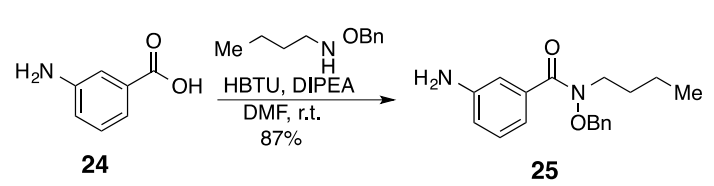

Scheme 3. Synthesis of RMS-575 (27)

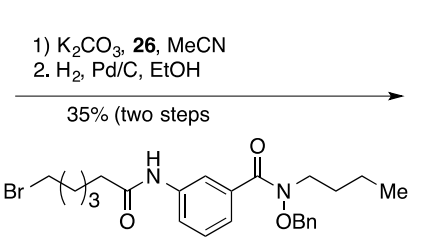

26

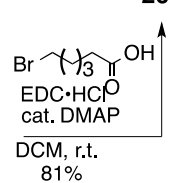

$81 \%$

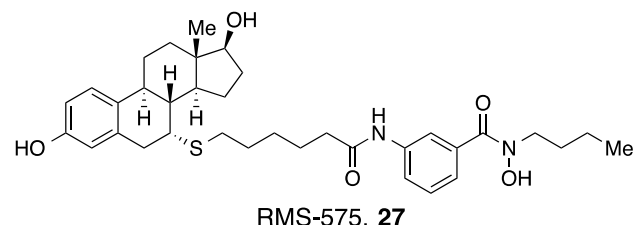

A fourth hybrid, RMS-575, was synthesized following a strategy employed extensively in our SAR studies on ER SUMOylation (Scheme 3). ${ }^{13 c, 34} 7 \alpha$-Mercaptoestradiol (23) was synthesized in a five step protocol from 12 (see Supporting Information). ${ }^{34}$ Thiol 23 was coupled with alkyl halide 26, prepared in 2 steps from 3-aminobenzoic acid (24), followed by debenzylation to afford hybrid RMS-575 (27) in 35\% yield over 2 steps.

Antiestrogenic profile of hybrids. The antiestrogenic activity of our hybrids was initially assessed using a bioluminescence resonance energy transfer (BRET) assay ${ }^{35}$ in transiently transfected HEK293 cells (Figure 
4 and Table 1). In this assay, luciferase is fused to ER $\alpha$ and an enhanced yellow fluorescent protein (eYFP) is fused to an LXXLL-containing coactivator peptide. In the presence of $\mathrm{E}_{2}$ or other ER agonists, the coactivator peptide associates with the ER $\alpha$ ligand-binding domain, resulting in energy transfer from luciferase to eYFP, while antagonists prevent coactivator association induced by agonists and thus reduce the BRET signal. Our four hybrids RMS-70 (11), RMS-162 (20), RMS-234 (22) and RMS-575 (27) showed suppression of BRET signal induced by E2 in a dose-dependent manner, consistent with antiestrogenic activity and similar to controls 4-hydroxytamoxifen (4-OHT) and ICI-164,384. In addition, transcriptional activity of ER $\alpha$ was measured using a luciferase reporter assay in T47D-KBLuc cells (ATCC ${ }^{\circ}$ CRL2865TM), which carry a stably integrated ERE3-TATA-Luciferase construct. ${ }^{36,37}$ While none of the hybrids were as potent as either ICI-164,384 or 4-OHT, all four hybrids displayed strong antiestrogenic activity (Table 1), with RMS-575 (27) again being the most potent.

Table 1. Antiestrogenic activity of hybrids measured by BRET and Luciferase assays, HDACi activity measured in vitro vs. purified HDAC3 and HDAC6, and antiproliferative activity of hybrids vs E2 promoted growth of MCF7 cells.

\begin{tabular}{llllll}
\hline \multicolumn{3}{l}{ Antiestrogenic Activity } & HDAC Activity & & $\begin{array}{l}\text { Antiproliferative } \\
\text { Activity }\end{array}$ \\
\hline Compound & $\begin{array}{l}\text { BRET } \\
\left(\mathrm{IC}_{50} \text { in } \mu \mathrm{M}\right)\end{array}$ & $\begin{array}{l}\text { Luciferase } \\
\left(\mathrm{IC}_{50} \text { in } \mu \mathrm{M}\right)\end{array}$ & $\begin{array}{l}\text { HDAC3 } \\
\left(\mathrm{IC}_{50} \text { in } \mu \mathrm{M}\right)\end{array}$ & $\begin{array}{l}\text { HDAC6 } \\
\left(\mathrm{IC}_{50} \text { in } \mu \mathrm{M}\right)\end{array}$ & $\begin{array}{l}\text { MCF7 } \\
\left(\mathrm{IC}_{50} \text { in } \mu \mathrm{M}\right)\end{array}$ \\
\hline ICI-164,384 (4) & 0.34 & 0.05 & $\mathrm{ND}$ & $\mathrm{ND}$ & 0.93 \\
4-OHT & 0.07 & 0.01 & $\mathrm{ND}$ & $\mathrm{ND}$ & 0.15 \\
SAHA (6) & $\mathrm{ND}$ & $\mathrm{ND}$ & 0.17 & 0.35 & 0.32 \\
entinostat (10) & $\mathrm{ND}$ & $\mathrm{ND}$ & 0.31 & $\mathrm{ND}$ & 0.35 \\
RMS-70 (11) & 0.51 & 1.06 & 0.96 & 1.15 & 2.93 \\
RMS-162 (20) & 0.21 & 0.72 & 3.18 & $>50.0$ & 1.90 \\
RMS-234 (22) & 2.55 & 2.10 & $>5.0$ & $>50.0$ & 9.11 \\
RMS-575 (27) & 0.05 & 0.18 & 1.55 & 43.7 & 0.34 \\
\hline
\end{tabular}

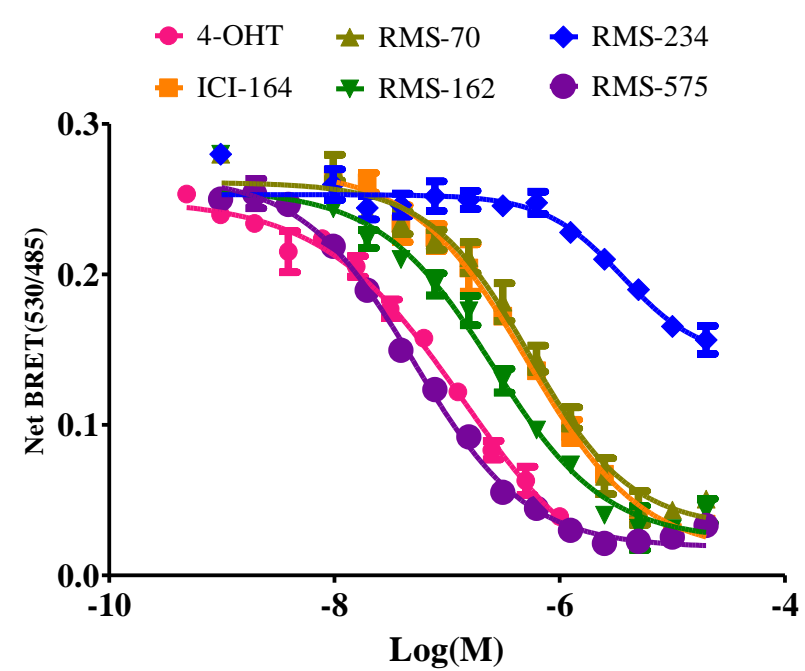

Figure 4. Induced release of eYFP-coactivator peptide from Luc-ER $\alpha$ in HEK293 cells by hybrids RMS-70 (11), RMS-162 (20), RMS-234 (22) and RMS-575 (27) as measured by BRET.

HDAC inhibition. The HDAC inhibitory activity of our hybrids was assessed in vitro using a competition assay against a standard fluorescent substrate using purified human recombinant HDAC3 and HDAC6 as models for Class I and II HDACs, respectively. ${ }^{38}$ Although displaying weaker potency than either SAHA or entinostat, all four hybrids displayed inhibitory activity against HDAC3, RMS-70 (11) being the most potent 
(0.96 $\mu \mathrm{M}$, Table 1). Against HDAC6, only RMS-70 (11) had a potency within one order of magnitude of SAHA, whereas the remaining hybrids were significantly less potent (Table 1). The selectivity of RMS-162 for HDAC3 is consistent with the general observation of benzamides as Class I selective HDACi's. ${ }^{39}$ Class I HDACs generally have a larger active site compared to Class II that allows access of the larger benzamides; this presumably also reflects the selectivity of RMS-234 and -575 for HDAC3 over HDAC6.
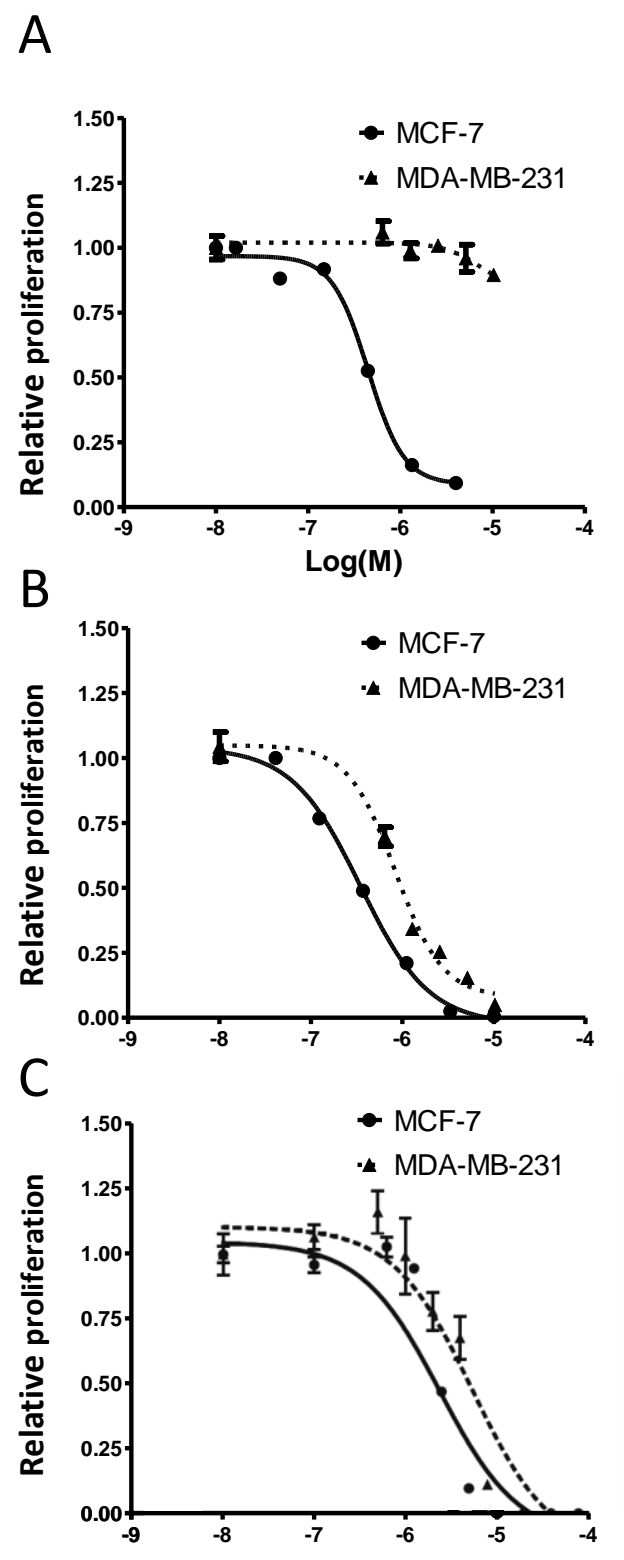

$\mathrm{D}$

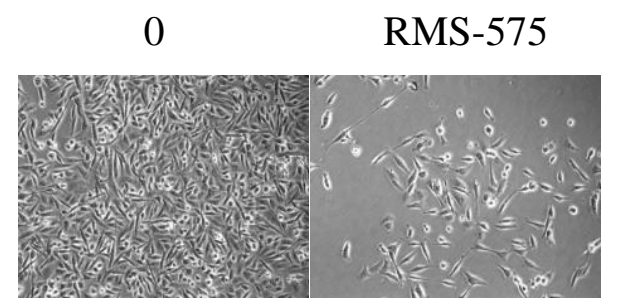

Figure 5. Antiproliferative activity of a) ICI-164,384, b) SAHA and c) RMS-575 in MCF-7 and MDA-MB-231 cell lines. $\mathrm{IC}_{50}$ values of $0.96 \mu \mathrm{M}$ and $5.02 \mu \mathrm{M}$ were measured for SAHA and RMS-575, respectively, in MDA-MB-231. d) Effect of RMS-575 $(4.0 \mu \mathrm{M})$ on survival of MDA-MB-231 cells. 
Antiproliferative studies. The studies above established that the four hybrids possessed both antiestrogenic and HDACi activity. We subsequently assessed the antiproliferative effects of the hybrids. All four hybrids were able to inhibit $E_{2}$-induced proliferation of MCF-7 cells, with RMS-575 (27) possessing an $\mathrm{IC}_{50}$ of $0.34 \mu \mathrm{M}$ (Table 1). This antiproliferative effect was similar to those of SAHA, entinostat, ICI164,384 and 4-OHT. This result demonstrates that bifunctional molecules have anti-proliferative activity in an ER+ cell line.

We further examined the antiproliferative effect of RMS-575 in ER-MDA-MB-231 cells. This cell line is sensitive to SAHA but not to antiestrogens. Intriguingly, MDA-MB-231 cells were sensitive to RMS-575 (Figure 5) with an $\mathrm{IC}_{50}$ within one order of magnitude of that of SAHA. This result demonstrates that the incorporation of an HDACi function affords antiproliferative activity to antiestrogen-based hybrids against ER-cell lines.

Docking studies. In order to study the binding modes of our hybrids, we performed molecular docking studies using Glide (Glide 5.0, Shrodinger LLC), which we previously used for antiestrogen SAR studies, ${ }^{13 \mathrm{c}}$ and with FITTED (part of the FORECASTER virtual screening suite), which has recently been parameterized for modeling HDAC. ${ }^{40}$ To model interactions with ER, we chose the crystal structure of ICI-164,384 bound to $\mathrm{ER} \beta$ (PDB code $1 \mathrm{HJ} 1)^{31}$ as a model as the coactivator binding regions of ERa and ER $\beta$ are very similar and would allow us to probe the effects of changing the side-chains of the antiestrogens. In this crystal structure, H12 is disordered and the long side chain interacts with the coactivator binding groove. Using Glide, we docked RMS-70 (11), RMS-162 (20), RMS-234 (22) and RMS-575 (27) in rigid mode along with ICI-164,384 (Figure 6). ICI164,384 self-docked in a conformation similar to that observed in the original crystal structure, with the side chain occupying the coactivator binding groove along the surface of the protein. A visual inspection of the poses of the hybrids showed a relationship between the polarity of the zinc binding group and the docking mode of the side chain. All side chains were sufficiently long to reach the highly hydrophobic coactivator-binding groove. The less polar benzamide, N-butyl hydroxamate and aryl Nbutyl hydroxamate of RMS-162, -234 and -575 , respectively, were able to interact with the coactivator binding groove in a manner analogous to ICI-164,384 (green). However, when the side chain was functionalized with a hydroxamic acid (RMS-70, 11, orange), the side chain did not interact with the CBG, but instead formed a hydrogen bond with Asp258 in $\mathrm{H} 2$.

In the absence of an x-ray crystal structures of HDAC3, we used for docking of our hybrids a homology model developed by Wiest. ${ }^{41}$ Using the parameters developed for HDAC docking in FITTED, we docked SAHA and hybrids RMS-70, -162, 234 and -575. As expected, docking of SAHA produced a pose

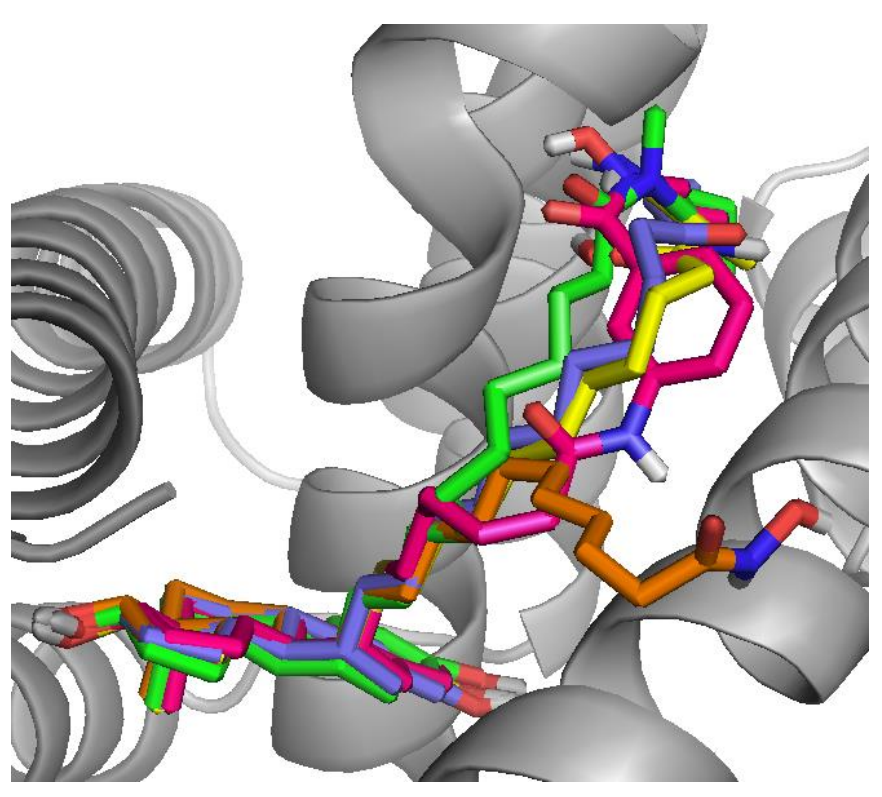

Figure 6. Docking overlay of RMS-70 (9, orange), RMS-162 (20, yellow), RMS-234 (22, violet) and RMS-575 (27, pink), with ICI-164,384 (green) bound to ER $\beta$.

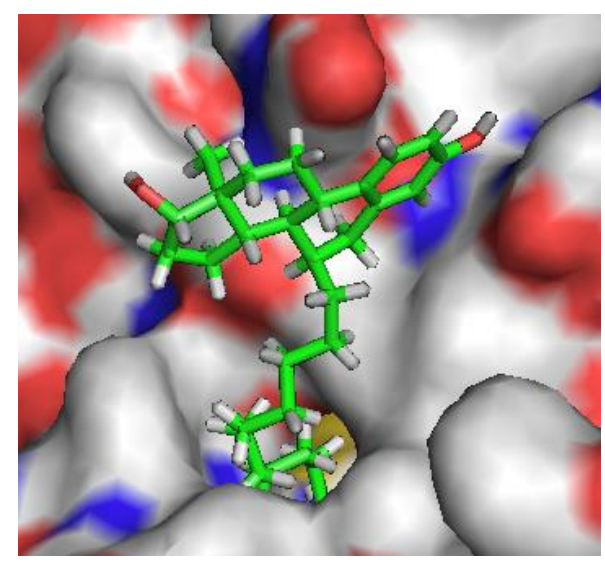

Figure 7. Docking RMS-70 in an HDAC3 homology model. 
similar to that found in HDAC2, ${ }^{42}$ with the hydroxamic acid forming a bidentate chelate with the active site zinc, the alkyl chain spanning the tube and the aromatic group binding in a groove at the surface. Docking of all four hybrids resulted in conformations leading to the expected bidentate chelates to zinc. The side chain of the most potent hybrid, RMS-70, effectively mimicked that of SAHA and formed a clear bidentate chelate to $\mathrm{Zn}$. The A,B-portion of the estradiol unit in RMS-70 fit into a slot on the surface near the opening to the active site (Figure 7). The other three hybrids docked in a similar manner with either the A,B or C/D portions binding in the surface slot. In the case of both N-butyl hydroxamates, the butyl group occupied the space normally filled by the aromatic ring of the benzamides. Importantly, the docking results strongly suggest that simultaneous binding of the hybrids to both targets is unlikely. In particular, the length of the chain between the zinc binding group and the estradiol unit is sufficiently short that the latter is closely associated with the HDAC surface (Figure 7) and would not be able to enter the ligand binding pocket of ER. Thus these hybrids, like those in the vitamin D class, ${ }^{27,28}$ are presumably interacting with both targets separately.

\section{Conclusions.}

Our results demonstrate that it is feasible to synthesize hybrid molecules that have inhibitory activity against both HDAC's and estrogen receptor. Starting from the ICI-164,384 backbone, modification of the side chain by inclusion of a zinc binding group resulted in gain of HDACi activity while retaining antiestrogenic activity. Given the use of HDACi's in combination with antiestrogens in breast cancer treatment, these molecules may constitute new leads for combined therapies. Future studies will aim at improving affinity for each target and testing efficacy in preclinical models.

\section{Experimental Protocols}

\section{Synthesis of hybrid molecules}

General Experimental. $\mathrm{CH}_{2} \mathrm{Cl}_{2}$ was distilled from $\mathrm{CaH}_{2}$ under argon. THF was distilled from sodium metal/benzophenone ketyl under argon. Acetonitrile was distilled from $4 \AA$ molecular sieves. DMF was dried over $4.0 \AA$ molecular sieves. All other commercial solvents and reagents were used as received from the Aldrich Chemical Company, Fischer Scientific, EMD Chemicals, BDH, and Steraloids. All glassware was flame dried and allowed to cool under a stream of dry argon. Silica gel (60A, 230-400 mesh) used in flash column chromatography was obtained from Silicycle and used as received. Analytical TLC was performed on precoated silica gel plates (Ultra Pure Silica Gel Plates purchased from EMD), visualized with a Spectroline UV254 lamp, and stained with either a 20\% phosphomolybdic acid in ethanol solution or a basic solution of $\mathrm{KMnO}_{4}$. Octadecyl-functionalized silica was used in flash chromatography was purchased from Sigma-Aldrich and used as received. ${ }^{1} \mathrm{H}$ and ${ }^{13} \mathrm{C}$ NMR, recorded at $300 \mathrm{MHz}$ and $75 \mathrm{MHz}$ respectively, were performed on a Varian Mercury 300 spectrometer. ${ }^{1} \mathrm{H}$ and ${ }^{13} \mathrm{C}$ NMR, recorded at $400 \mathrm{MHz}$ and $100 \mathrm{MHz}$, respectively, were performed on a Varian Mercury 400 spectrometer. ${ }^{1} \mathrm{H}$ and ${ }^{13} \mathrm{C} \mathrm{NMR}$, recorded at $500 \mathrm{MHz}$ and $126 \mathrm{MHz}$, respectively, were performed on a Varian Dante 500 spectrometer. Proton chemical shifts were internally referenced to the residual proton resonance in $\mathrm{CDCl}_{3}(\delta 7.26 \mathrm{ppm}), \mathrm{CD}_{3} \mathrm{OD}(\delta 3.31 \mathrm{ppm})$. Carbon chemical shifts were internally referenced to the deuterated solvent signals in $\mathrm{CDCl}_{3}(\delta 77.2 \mathrm{ppm})$ and $\mathrm{CD}_{3} \mathrm{OD}$ ( $\square 49.0 \mathrm{ppm}$ ). MS and HRMS were obtained at the McGill University chemistry department MS facilities using electrospray ionization (ESI) and atmospheric pressure chemical ionization (APCI). Infrared (IR) spectra were obtained using Nicolet Avatar 360 FT-IR infrared spectrophotometer. HPLC was used to verify the purity of compounds on an Agilent 1100 Series instrument equipped with a VWD detector, C18 column (Agilent, Zorbax Eclipse XDB-C18 150mm $\times 4.6 \mathrm{~mm}, 5 \mathrm{um}$ ), UV detection at $220 \mathrm{~nm}$.

(7S,8R,9S,13S,14S,17S)-7-(11-(benzyloxy)undecyl)-3,17-bis(methoxymethoxy)-13-methyl$\mathbf{7 , 8 , 9 , 1 1 , 1 2 , 1 3 , 1 4 , 1 5 , 1 6 , 1 7 - d e c a h y d r o - 6 H}$-cyclopenta[a]phenanthren-6-one (13). A solution of potassium tert-butoxide ( $381 \mathrm{mg} ; 3.4 \mathrm{mmol} ; 1.5$ equiv.) in tetrahydrofuran $(5 \mathrm{~mL})$ was added dropwise to a solution of $\mathbf{1 2}^{\mathbf{3 3}}$ (850 mg; $2.27 \mathrm{mmol} ; 1$ equiv.) in tetrahydrofuran $(20 \mathrm{~mL})$ at $0^{\circ} \mathrm{C}$. The reaction mixture was stirred at $0^{\circ} \mathrm{C}$ for $15 \mathrm{~min}$. followed by the addition of a solution of 1-benzyloxy-11-iodoundecane $(3.53 \mathrm{~g} ; 9.08 \mathrm{mmol}$; 4 equiv.) in tetrahydrofuran $(5 \mathrm{~mL})$ via cannula. The reaction mixture was slowly warmed up to r.t. overnight. 
The reaction was quenched with water $(10 \mathrm{~mL})$, extracted with ethyl acetate and washed with a saturated aqueous solution of ammonium chloride and brine. The organic layer was dried over anhydrous sodium sulfate, filtered and concentrated. The residue was purified by chromatography on silica gel eluting a gradient of 5\% to $15 \%$ of ethyl acetate in hexanes increasing 5\% every two column volumes to give $\mathbf{1 3}$ as a colourless oil $(749 \mathrm{mg}, 52 \%) .{ }^{1} \mathrm{H}$ NMR $\left(400 \mathrm{MHz} ; \mathrm{CDCl}_{3}\right): \delta 7.68(\mathrm{~d}, J=2.7 \mathrm{~Hz}, 1 \mathrm{H}), 7.34-7.28(\mathrm{~m}, 6 \mathrm{H}), 7.19(\mathrm{dd}, J$ $=8.6,2.7 \mathrm{~Hz}, 1 \mathrm{H}), 5.20(\mathrm{~s}, 2 \mathrm{H}), 4.68-4.64(\mathrm{~m}, 2 \mathrm{H}), 4.50(\mathrm{~s}, 2 \mathrm{H}), 3.65(\mathrm{t}, J=8.4 \mathrm{~Hz}, 1 \mathrm{H}), 3.48-3.44(\mathrm{~m}, 5 \mathrm{H})$, $3.37(\mathrm{~s}, 3 \mathrm{H}), 2.71(\mathrm{td}, J=10.9,3.9 \mathrm{~Hz}, 1 \mathrm{H}), 2.47-2.35(\mathrm{~m}, 2 \mathrm{H}), 2.13-1.99(\mathrm{~m}, 3 \mathrm{H}), 1.63-1.17(\mathrm{~m}, 28 \mathrm{H}), 0.81$ (s, 3H). IR (thin film) 3005, 2925, 2853, 1668, 1453, 1275, 906, 764. HRMS (ESI) m/z calcd for [(M+Na) $\left.{ }^{+}\right]$ $=657.4131$, found $=657.4133$

(7S,8R,9S,13S,14S,17S)-7-(11-(benzyloxy)undecyl)-3,17-dihydroxy-13-methyl$\mathbf{7 , 8 , 9 , 1 1 , 1 2 , 1 3 , 1 4 , 1 5 , 1 6 , 1 7 - d e c a h y d r o - 6} \boldsymbol{H}$-cyclopenta[a]phenanthren-6-one (14). A $6 \mathrm{M} \mathrm{HCl}$ solution (10 $\mathrm{mL})$ was added to a solution of $\mathbf{1 3}(650 \mathrm{mg}, 1.02 \mathrm{mmol}, 1.0$ equiv. $)$ in tetrahydrofuran $(10 \mathrm{~mL})$ at $0^{\circ} \mathrm{C}$. The reaction mixture was allowed to warm up to r.t. and stirred for $20 \mathrm{~h}$. The reaction was cooled to $0^{\circ} \mathrm{C}$ and the acid was neutralized with a $6 \mathrm{M}$ aqueous solution of $\mathrm{NaOH}(9.5 \mathrm{~mL})$. The reaction was extracted with ethyl acetate $(30 \mathrm{~mL} \mathrm{X} \mathrm{2)}$ and the mixed organic layers were washed with a saturated aqueous solution of ammonium chloride $(20 \mathrm{~mL})$ and brine $(20 \mathrm{~mL})$. The organic layer was dried over anhydrous sodium sulfate, filtered and concentrated. The residue was purified by chromatography on silica gel eluting $10 \%$ ethyl acetate in toluene to obtain $\mathbf{1 4}$ as a colourless oil $\left(502 \mathrm{mg} ; 90 \%\right.$ yield). ${ }^{1} \mathrm{H}$ NMR $\left(500 \mathrm{MHz} ; \mathrm{CDCl}_{3}\right): \delta 7.59$ (d, $J=$ $2.9 \mathrm{~Hz}, 1 \mathrm{H}), 7.34-7.27(\mathrm{~m}, 6 \mathrm{H}), 7.06(\mathrm{dd}, J=8.5,2.9 \mathrm{~Hz}, 1 \mathrm{H}), 4.51(\mathrm{~s}, 2 \mathrm{H}), 3.79(\mathrm{t}, J=8.5 \mathrm{~Hz}, 1 \mathrm{H}), 3.47(\mathrm{t}$, $J=6.7 \mathrm{~Hz}, 2 \mathrm{H}), 2.68(\mathrm{td}, J=11.3,4.5 \mathrm{~Hz}, 1 \mathrm{H}), 2.45(\mathrm{dt}, J=11.6,3.2 \mathrm{~Hz}, 1 \mathrm{H}), 2.38(\mathrm{dt}, J=9.7,3.7 \mathrm{~Hz}, 1 \mathrm{H})$, 2.17-2.05 (m, 2H), 1.99-1.95 (m, 2H), 1.63-1.45 (m, 8H), 1.39-1.14 (m, 19H), 0.78 (s, 3H). ${ }^{13} \mathrm{C} \mathrm{NMR}(126$ $\left.\mathrm{MHz} ; \mathrm{CDCl}_{3}\right): \delta 202.1,155.1,138.6,138.2,132.2,128.5,127.82,127.64,127.4,121.7,113.6,81.8,73.0$, 70.6, 48.9, 45.4, 43.4, 42.8, 37.5, 36.6, 30.4, 29.81, 29.72, 29.63, 29.60, 29.58, 29.54, 29.50, 27.4, 26.7, 26.2, 23.8, 22.4, 11.1. HRMS (APCI) $\mathrm{m} / \mathrm{z}$ calcd for $\left[(\mathrm{M}+\mathrm{H})^{+}\right]=547.3787$, found $=547.3776$

(7R,8R,9S,13S,14S,17S)-7-(11-(benzyloxy)undecyl)-13-methyl-7,8,9,11,12,13,14,15,16,17-

decahydro-6H-cyclopenta[a]phenanthrene-3,17-diol (15). Boron trifluoride diethyl ether $(680 \mu \mathrm{L} ; 5.41$ mmol; 6 equiv.) was added dropwise to a solution of $\mathbf{1 4}(480 \mathrm{mg} ; 0.901 \mathrm{mmol} ; 1$ equiv.) in dichloromethane $(20 \mathrm{~mL})$ at $0^{\circ} \mathrm{C}$, followed by the addition of triethylsilane $(1.44 \mathrm{~mL} ; 9.01 \mathrm{mmol} ; 10$ equiv. $)$. The mixture was stirred at r.t. for $15 \mathrm{~h}$. The reaction was quenched with a saturated aqueous solution of sodium bicarbonate until reaching $\mathrm{pH} 8$. The aqueous phase was extracted with dichloromethane $(20 \mathrm{~mL})$ and the combined organic layers were washed with brine $(30 \mathrm{~mL})$. The organic layer was dried over anhydrous sodium sulfate, filtered and concentrated. The residue was purified by chromatography on silica gel eluting $10 \%$ ethyl acetate in toluene to obtain 15 as a colourless oil $(403 \mathrm{mg}, 86 \%) .{ }^{1} \mathrm{H}$ NMR $\left(500 \mathrm{MHz} ; \mathrm{CDCl}_{3}\right): \delta 7.35-7.27(\mathrm{~m}, 5 \mathrm{H})$, $7.14(\mathrm{~d}, J=8.6 \mathrm{~Hz}, 1 \mathrm{H}), 6.62(\mathrm{dd}, J=8.4,2.6 \mathrm{~Hz}, 1 \mathrm{H}), 6.54(\mathrm{~d}, J=2.4 \mathrm{~Hz}, 1 \mathrm{H}), 4.52(\mathrm{~s}, 2 \mathrm{H}), 3.76(\mathrm{t}, J=7.1$ $\mathrm{Hz}, 1 \mathrm{H}), 3.48(\mathrm{t}, J=6.7 \mathrm{~Hz}, 2 \mathrm{H}), 2.86(\mathrm{dd}, J=16.7,5.0 \mathrm{~Hz}, 1 \mathrm{H}), 2.71(\mathrm{~d}, J=16.6 \mathrm{~Hz}, 1 \mathrm{H}), 2.33-2.28(\mathrm{~m}$, 2H), 2.17-2.09 (m, 1H), 1.92-1.89 (m, 1H), 1.75-1.70 (m, 1H), 1.64-1.13 (m, 29H), 0.79 (s, 3H). ${ }^{13} \mathrm{C}$ NMR $\left(126 \mathrm{MHz} ; \mathrm{CDCl}_{3}\right): \delta 153.6,138.7,137.3,131.9,128.5,127.83,127.66,127.2,116.3,112.96,112.95,82.2$, 73.0, 70.6, 46.6, 43.5, 42.1, 38.2, 37.0, 34.7, 33.3, 30.6, 30.00, 29.81, 29.75, 29.74, 29.64, 29.56, 28.2 27.4, 26.3, 25.7, 22.8, 11.2 HRMS (APCI) $\mathrm{m} / \mathrm{z}$ calcd for $\left[(\mathrm{M}+\mathrm{H})^{+}\right]=533.3995$, found $=533.3973$

$(7 R, 8 R, 9 S, 13 S, 14 S, 17 S)-7-(11-(b e n z y l o x y) u n d e c y l)-13-m e t h y l-7,8,9,11,12,13,14,15,16,17-$ decahydro-6H-cyclopenta[a]phenanthrene-3,17-diyl diacetate $(\mathbf{1 6})$. Acetic anhydride $(320 \mu \mathrm{L} ; 3.35$ mmol; 10 equiv.) was added to a solution of 15 (355 mg; $0.67 \mathrm{mmol} ; 2$ equiv.) in pyridine (5 mL) with a catalytic amount of 4-dimethylaminopyridine and stirred at r.t. for $5 \mathrm{~h}$. The reaction was concentrated and directly purified by chromatography on silica gel eluting 10\% ethyl acetate in hexanes to obtain $\mathbf{1 6}$ as a colourless oil (406 mg, 99\%). ${ }^{1} \mathrm{H}$ NMR $\left(500 \mathrm{MHz} ; \mathrm{CDCl}_{3}\right): \delta 7.34(\mathrm{~d}, J=4.4 \mathrm{~Hz}, 4 \mathrm{H}), 7.29-7.28(\mathrm{~m}, 1 \mathrm{H})$, 7.27-7.26 (m, 1H), $6.84(\mathrm{dd}, J=8.5,2.5 \mathrm{~Hz}, 1 \mathrm{H}), 6.78(\mathrm{~d}, J=2.5 \mathrm{~Hz}, 1 \mathrm{H}), 4.70(\mathrm{t}, J=8.5 \mathrm{~Hz}, 1 \mathrm{H}), 4.50(\mathrm{~s}$, $2 \mathrm{H}), 3.46(\mathrm{t}, J=6.7 \mathrm{~Hz}, 2 \mathrm{H}), 2.90(\mathrm{dd}, J=17.0,5.3 \mathrm{~Hz}, 1 \mathrm{H}), 2.76(\mathrm{~d}, J=16.7 \mathrm{~Hz}, 1 \mathrm{H}), 2.40-2.29(\mathrm{~m}, 3 \mathrm{H})$, $2.28(\mathrm{~s}, 3 \mathrm{H}), 2.23(\mathrm{dq}, J=14.0,4.6 \mathrm{~Hz}, 1 \mathrm{H}), 2.06(\mathrm{~s}, 3 \mathrm{H}), 1.85(\mathrm{dt}, J=12.4,2.9 \mathrm{~Hz}, 1 \mathrm{H}), 1.77-1.74(\mathrm{~m}, 1 \mathrm{H})$, $1.68-1.21(\mathrm{~m}, 27 \mathrm{H}), 0.82(\mathrm{~s}, 3 \mathrm{H}) .{ }^{13} \mathrm{C} \mathrm{NMR}\left(126 \mathrm{MHz} ; \mathrm{CDCl}_{3}\right): \delta 171.3,170.0,148.6,138.8,137.29,137.25$, 128.5, 127.74, 127.57, 127.1, 122.5, 118.8, 82.9, 73.0, 70.7, 46.4, 43.1, 41.5, 38.2, 37.2, 34.6, 33.2, 30.08, 
29.91, 29.89, 29.78, 29.72, 29.61, 28.3, 27.6, 27.1, 26.3, 25.8, 22.9, 21.34, 21.30, 12.2. IR (thin film) 2923, 2852, 1763, 1733, 1368, 1275, 1206, 764 HRMS $(\mathrm{ESI}) \mathrm{m} / \mathrm{z}$ calcd for $\left[(\mathrm{M}+\mathrm{Na})^{+}\right]=639.4025$, found $=$ 639.4025

(7R,8R,9S,13S,14S,17S)-7-(11-hydroxyundecyl)-13-methyl-7,8,9,11,12,13,14,15,16,17-decahydro6H-cyclopenta[ $\boldsymbol{a}]$ phenanthrene-3,17-diyl diacetate (17). Palladium (10\% on carbon; 0.10 equiv.) was added to a solution of 16 (406 mg; $0.66 \mathrm{mmol}$; 1 equiv.) in ethanol $(3 \mathrm{~mL})$, and was stirred at r.t. for $8 \mathrm{~h}$ under a hydrogen atmosphere. The reaction mixture was filtered through celite and concentrated. The residue was purified by chromatography on silica gel eluting $15 \%$ ethyl acetate in hexanes to obtain $\mathbf{1 7}$ as a colourless oil (320 mg, 92\%). ${ }^{1} \mathrm{H}$ NMR (500 MHz; $\left.\mathrm{CDCl}_{3}\right): \delta 7.27(\mathrm{~d}, J=9.0 \mathrm{~Hz}, 1 \mathrm{H}), 6.84(\mathrm{dd}, J=8.5,2.5 \mathrm{~Hz}, 1 \mathrm{H}), 6.78$ $(\mathrm{d}, J=2.4 \mathrm{~Hz}, 1 \mathrm{H}), 4.69(\mathrm{t}, J=8.5 \mathrm{~Hz}, 1 \mathrm{H}), 3.63(\mathrm{t}, J=6.7 \mathrm{~Hz}, 2 \mathrm{H}), 2.92-2.87(\mathrm{~m}, 1 \mathrm{H}), 2.75(\mathrm{~d}, J=16.8 \mathrm{~Hz}$, 1H), 2.39-2.29 (m, 2H), $2.27(\mathrm{~s}, 3 \mathrm{H}), 2.22(\mathrm{dq}, J=13.6,4.7 \mathrm{~Hz}, 1 \mathrm{H}), 2.05(\mathrm{~s}, 3 \mathrm{H}), 1.85$ (dt, $J=12.4,2.9 \mathrm{~Hz}$, $1 \mathrm{H}), 1.76-1.74(\mathrm{~m}, 1 \mathrm{H}), 1.66-1.17(\mathrm{~m}, 28 \mathrm{H}), 0.82(\mathrm{~s}, 3 \mathrm{H}) .{ }^{13} \mathrm{C} \mathrm{NMR}\left(126 \mathrm{MHz} ; \mathrm{CDCl}_{3}\right): \delta 171.2,169.8$, 148.4, 137.1, 126.9, 122.3, 118.6, 82.8, 63.0, 46.2, 42.9, 41.3, 38.1, 37.0, 34.5, 33.1, 32.8, 29.9, 29.64, 29.56, 29.53, 29.40, 28.1, 27.5, 26.9, 25.72, 25.58, 22.7, 21.19, 21.15. IR (thin film) $3443,2922,2852,1763,1733$, $1370,1243,750 \mathrm{HRMS}(\mathrm{ESI}) \mathrm{m} / \mathrm{z}$ calcd for $\left[(\mathrm{M}+\mathrm{Na})^{+}\right]=549.3556$, found $=549.3555$

11-((7R,8R,9S,13S,14S,17S)-3,17-diacetoxy-13-methyl-7,8,9,11,12,13,14,15,16,17-decahydro-6Hcyclopenta[ $[\boldsymbol{a}]$ phenanthren-7-yl)undecanoic acid (18): A solution of dimethylsulfoxide $(130 \mu \mathrm{L} ; 1.81$ mmol ; 3.0 equiv.) in dichloromethane $(2.0 \mathrm{~mL})$ at $-78^{\circ} \mathrm{C}$ was slowly added via cannula over 5 min to a solution of oxalyl chloride $(80 \mu \mathrm{L}, 0.92 \mathrm{mmol}, 1.5$ equiv. $)$ in dichloromethane $(2.0 \mathrm{~mL})$ at $-78^{\circ} \mathrm{C}$. The reaction was stirred $15 \mathrm{~min}$ at $-78^{\circ} \mathrm{C}$. A solution of $17(320 \mathrm{mg}$; $0.61 \mathrm{mmol} ; 1$ equiv.) in dichloromethane $(2 \mathrm{~mL})$ was slowly added to the reaction mixture and stirred $1 \mathrm{~h}$ at $-78^{\circ} \mathrm{C}$. Triethylamine $(426 \mu \mathrm{L} ; 3.05 \mathrm{mmol} ; 5.0$ equiv) was added to the reaction mixture in one portion and the mixture was allowed to warm up to r.t. for 15 min. Water $(3 \mathrm{~mL})$ was added and the aqueous phase was extracted with dichlorometane $(5 \mathrm{~mL})$. The organic phases were combined, concentrated and further dissolved in ethyl acetate $(20 \mathrm{~mL})$, washed with a $0.1 \mathrm{M}$ solution of hydrochloric acid $(2 \times)$ and brine. The organic phase was dried under anhydrous sodium sulfate, filtered and concentrated. The residue and 2-methyl-2-butene ( $2.6 \mathrm{~mL} ; 24.4 \mathrm{mmol} ; 40$ equiv.) were dissolved in tert-butanol $(7.0 \mathrm{~mL})$ and a solution of sodium chlorite $(165 \mathrm{mg} ; 1.83 \mathrm{mmol} ; 3$ equiv.) and sodium dihydrogen phosphate $(415 \mathrm{mg} ; 3.05 \mathrm{mmol} ; 5$ equiv.) in water $(3.2 \mathrm{~mL})$ was added in one portion to the reaction mixture. This biphasic mixture was stirred vigorously for $3 \mathrm{~h}$. The reaction was extracted with diethyl ether $(3 \times)$ and the combined organic layers were washed with brine $(30 \mathrm{~mL})$. The residue was purified by chromatography on silica gel eluting 5\% ethyl acetate and 1\% acetic acid in toluene to obtain $\mathbf{1 8}$ as a colourless oil $\left(275 \mathrm{mg} ; 84 \%\right.$ yield). ${ }^{1} \mathrm{H}$ NMR $\left(500 \mathrm{MHz} ; \mathrm{CDCl}_{3}\right): \delta 7.27(\mathrm{~d}, J=8.9 \mathrm{~Hz}, 1 \mathrm{H}), 6.84(\mathrm{dd}, J=$ $8.5,2.5 \mathrm{~Hz}, 1 \mathrm{H}), 6.78(\mathrm{~d}, J=2.5 \mathrm{~Hz}, 1 \mathrm{H}), 4.70(\mathrm{t}, J=8.5 \mathrm{~Hz}, 1 \mathrm{H}), 2.90(\mathrm{dd}, J=16.9,5.4 \mathrm{~Hz}, 1 \mathrm{H}), 2.75(\mathrm{~d}, J$ $=16.6 \mathrm{~Hz}, 1 \mathrm{H}), 2.39-2.29(\mathrm{~m}, 4 \mathrm{H}), 2.28(\mathrm{~s}, 3 \mathrm{H}), 2.22(\mathrm{dq}, J=13.6,4.7 \mathrm{~Hz}, 1 \mathrm{H}), 2.06(\mathrm{~s}, 3 \mathrm{H}), 1.85(\mathrm{dt}, J=$ 12.3, $2.8 \mathrm{~Hz}, 1 \mathrm{H}), 1.76-1.74(\mathrm{~m}, 1 \mathrm{H}), 1.67-1.15(\mathrm{~m}, 29 \mathrm{H}), 0.82(\mathrm{~s}, 3 \mathrm{H}) .{ }^{13} \mathrm{C} \mathrm{NMR}\left(126 \mathrm{MHz} ; \mathrm{CDCl}_{3}\right): \delta$ 179.7, 171.5, 170.0, 148.6, 137.29, 137.24, 127.1, 122.5, 118.8, 82.9, 46.4, 43.1, 41.5, 38.2 , 37.2, 34.6, 34.1, $33.2,30.0,29.80,29.67,29.53,29.34,29.17,28.3,27.6,27.1,25.8,24.8,22.9,21.34,21.30,12.2$ IR (thin film) 2923, 2853, 1762, 1732, 1706, 1370, 1275, 1206, 764 HRMS (ESI) m/z calcd for $\left[(\mathrm{M}+\mathrm{Na})^{+}\right]=$ 539.3349 , found $=539.3349$

Methyl

11-((7R,8R,9S,13S,14S,17S)-3,17-dihydroxy-13-methyl-7,8,9,11,12,13,14,15,16,17decahydro-6H-cyclopenta[a]phenanthren-7-yl)undecanoate (19): 18 (150 mg; $0.28 \mathrm{mmol} ; 1.0$ equiv.) was dissolved in $\mathrm{MeOH}$. Two drops of concentrated $\mathrm{HCl}$ were added to the mixture and the reaction was stirred overnight. The reaction was then concentrated and purified by chromatography over silica gel eluting $40 \%$ ethyl acetate in hexanes and gave 19 as an oil $(123 \mathrm{mg} ; 94 \%) .{ }^{1} \mathrm{H}$ NMR $\left(400 \mathrm{MHz} ; \mathrm{CDCl}_{3}\right): \delta 7.14(\mathrm{~d}$, $J=8.5 \mathrm{~Hz}, 1 \mathrm{H}), 6.63(\mathrm{dd}, J=8.4,2.6 \mathrm{~Hz}, 1 \mathrm{H}), 6.55(\mathrm{~d}, J=2.4 \mathrm{~Hz}, 1 \mathrm{H}), 5.27(\mathrm{~s}(\mathrm{br}), 1 \mathrm{H}), 3.76(\mathrm{t}, J=8.5 \mathrm{~Hz}$, $1 \mathrm{H}), 3.67(\mathrm{~s}, 3 \mathrm{H}), 2.86(\mathrm{dd}, J=16.9,5.1 \mathrm{~Hz}, 1 \mathrm{H}), 2.71(\mathrm{~d}, J=16.8 \mathrm{~Hz}, 1 \mathrm{H}), 2.30(\mathrm{~m}, 4 \mathrm{H}), 2.18-2.06(\mathrm{~m}, 1 \mathrm{H})$, $1.90(\mathrm{dd}, J=12.3,2.8 \mathrm{~Hz}, 1 \mathrm{H}), 1.74-1.17(\mathrm{~m}, 28 \mathrm{H}), 0.78(\mathrm{~s}, 3 \mathrm{H}) .{ }^{13} \mathrm{C}$ NMR $\left(75 \mathrm{MHz} ; \mathrm{CDCl}_{3}\right): \delta 174.78$, 153.7, 137.3, 131.9, 127.2, 116.3, 113.0, 82.2, 51.7, 46.6, 43.5, 42.1, 38.2, 37.0, 34.7, 34.3, 33.3, 30.7, 30.0, 

493.3294 , found $=493.3270$

\section{1-((7R,8R,9S,13S,14S,17S)-3,17-dihydroxy-13-methyl-7,8,9,11,12,13,14,15,16,17-decahydro-6H-} cyclopenta $[a]$ phenanthren-7-yl)- $N$-hydroxyundecanamide (11): Hydroxylamine $(50 \% \mathrm{v} / \mathrm{v}$ in water, 2.0 $\mathrm{mL}, 31.85 \mathrm{mmol}, 500$ equiv.) at $0{ }^{\circ} \mathrm{C}$ was added to 19 (30 mg, $0.064 \mathrm{mmol}, 1$ equiv.) dissolved in a 1:2:3 mixture of $\mathrm{H}_{2} \mathrm{O} / \mathrm{MeOH} / \mathrm{THF}$ followed by the addition potassium hydroxide $(3.0 \mathrm{M}, 150 \mu \mathrm{L}, 0.45 \mathrm{mmol}, 7.0$ equiv.). The reaction mixture was kept in an ice bath and was slowly warmed up to r.t. and stirred for $24 \mathrm{~h}$. The reaction mixture was acidified to $\mathrm{pH} 2-3$ with a $0.5 \mathrm{M} \mathrm{HCl}$ and the biphasic mixture was concentrated in vacuum in the presence of celite to dry load the product for purification by reverse phase chromatography eluting $30-95 \%$ methanol in water to obtain 11 as a colourless oil (21 mg; 70\% yield). Purity by HPLC: $>99 \%, \mathrm{t}_{\mathrm{r}}=13.89$, conditions: linear gradient from $95 \% \mathrm{H}_{2} \mathrm{O}$ and $5 \% \mathrm{MeOH}$ to $100 \% \mathrm{MeOH}$ with $0.1 \%$ formic acid over $20 \mathrm{~min} .{ }^{1} \mathrm{H}$ NMR (500 MHz; $\left.\mathrm{CD}_{3} \mathrm{OD}\right): \delta 7.08(\mathrm{~d}, J=8.5 \mathrm{~Hz}, 1 \mathrm{H}), 6.54(\mathrm{dd}, J=8.4,2.5 \mathrm{~Hz}, 1 \mathrm{H})$, $6.46(\mathrm{~d}, J=2.3 \mathrm{~Hz}, 1 \mathrm{H}), 3.67(\mathrm{t}, J=8.6 \mathrm{~Hz}, 1 \mathrm{H}), 2.84-2.79(\mathrm{~m}, 1 \mathrm{H}), 2.69(\mathrm{~d}, J=16.5 \mathrm{~Hz}, 1 \mathrm{H}), 2.33-2.25(\mathrm{~m}$, $3 \mathrm{H}), 2.08-2.02(\mathrm{~m}, 3 \mathrm{H}), 1.93-1.90(\mathrm{~m}, 1 \mathrm{H}), 1.75-1.72(\mathrm{~m}, 1 \mathrm{H}), 1.62-1.20(\mathrm{~m}, 24 \mathrm{H}), 0.78(\mathrm{~s}, 3 \mathrm{H}) .{ }^{13} \mathrm{C}$ NMR (126 MHz; CD $\left.{ }_{3} \mathrm{OD}\right): \delta$ 169.8, 156.0, 137.6, 131.9, 127.9, 116.9, 113.9, 82.6, 47.8, 44.5, 43.7, 39.7, 38.3, $35.8,34.7,33.8,31.0,30.70,30.61,30.59,30.4,30.2,29.1,28.6,26.8,26.5,23.6,11.7$. HRMS (ESI): $\mathrm{m} / \mathrm{z}$ calcd for $\left[(\mathrm{M}+\mathrm{Na})^{+}\right]=494.3246$, found $=494.3238$

\section{$N$-(2-aminophenyl)-11-((7R,8R,9S,13S,14S,17S)-3,17-dihydroxy-13-methyl-}

$\mathbf{7 , 8 , 9 , 1 1 , 1 2 , 1 3 , 1 4 , 1 5 , 1 6 , 1 7 - d e c a h y d r o - 6 H}$-cyclopenta[a]phenanthren-7-yl)undecanamide (20): HBTU ( $89 \mathrm{mg}, 0.24 \mathrm{mmol}, 1.1$ equiv.) was added at r.t. in one portion to a solution of carboxylic acid 18 (116 mg, $0.21 \mathrm{mmol}, 1.0$ equiv.), $o$-aminoaniline ( $23 \mathrm{mg}, 0.21 \mathrm{mmol}, 1.0$ equiv.) and DIPEA (111 $\mu \mathrm{L}, 0.64 \mathrm{mmol}, 3.0$ equiv.) in dry DMF (3 mL) under an argon atmosphere. The reaction was stirred for $2 \mathrm{~h}$ at r.t. and was quenched with brine (5x the reaction volume). The reaction was extracted with ethyl acetate $(2 \times)$ and the combined organic layers were washed with water $(4 \times)$, aqueous $0.1 \mathrm{M} \mathrm{HCl}$, saturated solution of ammonium chloride and brine. The organic layer was dried over anhydrous sodium sulfate, filtered and concentrated. The reaction mixture from the peptide coupling was dissolved in $\mathrm{MeOH}(5 \mathrm{~mL})$ and $\mathrm{K}_{2} \mathrm{CO}_{3}(89 \mathrm{mg}, 0.64$ mmol, 3.0 equiv.) were added to the solution and the reaction was stirred for $5 \mathrm{~h}$ at r.t. and concentrated. The residue was dried loaded into silica and purified by chromatography on silica gel eluting $15 \%$ ethyl acetate in toluene to obtain 20 as a colourless oil (108 mg, 92\%). Purity by HPLC: 97\%, $\mathrm{t}_{\mathrm{r}}=8.08$, conditions: linear gradient from $50 \% \mathrm{H}_{2} \mathrm{O}$ and $50 \% \mathrm{MeOH}$ to $100 \% \mathrm{MeOH}$ with $0.1 \%$ formic acid over $20 \mathrm{~min} .{ }^{1} \mathrm{H}$ NMR $(500$ $\left.\mathrm{MHz} ; \mathrm{CDCl}_{3}\right): \delta 7.24(\mathrm{~s}, 1 \mathrm{H}), 7.17(\mathrm{dd}, J=8.1,1.3 \mathrm{~Hz}, 1 \mathrm{H}), 7.12(\mathrm{~d}, J=8.4 \mathrm{~Hz}, 1 \mathrm{H}), 7.07(\mathrm{td}, J=7.7,1.3$ $\mathrm{Hz}, 1 \mathrm{H}), 6.81(\mathrm{~m}, 2 \mathrm{H}), 6.62-6.60(\mathrm{~m}, 1 \mathrm{H}), 6.54(\mathrm{~d}, J=2.6 \mathrm{~Hz}, 1 \mathrm{H}), 3.88(\mathrm{~s}(\mathrm{br}), 2 \mathrm{H}), 3.74(\mathrm{t}, J=8.5 \mathrm{~Hz}, 1 \mathrm{H})$, $2.84(\mathrm{dd}, J=16.7,5.1 \mathrm{~Hz}, 1 \mathrm{H}), 2.70(\mathrm{~d}, J=16.7 \mathrm{~Hz}, 1 \mathrm{H}), 2.39(\mathrm{t}, J=7.6 \mathrm{~Hz}, 2 \mathrm{H}), 2.32-2.27(\mathrm{~m}, 2 \mathrm{H}), 2.16-$ $2.10(\mathrm{~m}, 1 \mathrm{H}), 1.92-1.88(\mathrm{~m}, 1 \mathrm{H}), 1.72(\mathrm{dt}, J=14.9,7.5 \mathrm{~Hz}, 2 \mathrm{H}), 1.64-1.56(\mathrm{~m}, 2 \mathrm{H}), 1.50-1.14(\mathrm{~m}, 19 \mathrm{H}), 0.77$ (s, 3H). ${ }^{13} \mathrm{C}$ NMR $\left(75 \mathrm{MHz} ; \mathrm{CDCl}_{3}\right): \delta 172.4,153.9,140.8,137.2,131.7,127.4,127.1,125.4,124.6,119.9$, 118.5, 116.3, 113.0, 82.2, 46.6, 43.5, 42.2, 38.3, 37.23, 37.07, 34.8, 33.4, 30.7, 29.7, 29.42, 29.38, 29.34, 29.30, 27.9, 27.4, 26.0, 25.4, 22.8, 11.3HRMS (APCI): $\mathrm{m} / \mathrm{z}$ calcd for $\left[(\mathrm{M}+\mathrm{H})^{+}\right]=547.3900$, found $=547.3879$

\section{$N$-(benzyloxy)- $N$-butyl-11-((7R,8R,9S,13S,14S,17S)-3,17-dihydroxy-13-methyl-}

\section{7,8,9,11,12,13,14,15,16,17-decahydro-6H-cyclopenta[a]phenanthren-7-yl)undecanamide (21): HBTU} (105 mg, $0.28 \mathrm{mmol}, 1.1$ equiv.) was added at r.t. in one portion to a solution of carboxylic acid 18 (30 $\mathrm{mg}$, $0.06 \mathrm{mmol}, 1.0$ equiv.), N-butyl-O-benzyl hydroxylamine (10 mg, $0.06 \mathrm{mmol}, 1.0$ equiv.) and DIPEA (30 $\mu \mathrm{L}, 0.17 \mathrm{mmol}, 3.0$ equiv.) in dry DMF (3.0 mL) under an argon atmosphere. The reaction was stirred for 2 $\mathrm{h}$ at r.t. and was quenched with brine $(15 \mathrm{~mL})$. The reaction was extracted with ethyl acetate $(2 \times)$ and the combined organic layers were washed with water $(4 \times)$, aqueous $0.1 \mathrm{M} \mathrm{HCl}$, saturated solution of ammonium chloride and brine. The organic layer was dried over anhydrous sodium sulfate, filtered and concentrated. The resulting crude reaction was dissolved in methanol $(3.0 \mathrm{~mL})$ and $\mathrm{K}_{2} \mathrm{CO}_{3}(23 \mathrm{mg}, 0.17 \mathrm{mmol}, 3.0$ equiv.) was added to the solution and stirred for 4 . The reaction mixture was acidified to $\mathrm{pH} 4-5$ and was concentrated over silica gel. The residue was purified by chromatography on silica gel eluting $15 \%$ ethyl acetate in toluene to give 21 as a colourless oil (37 mg, 90\%). Purity by HPLC: $96 \%, \mathrm{t}_{\mathrm{r}}=4.58$, conditions: linear gradient from 
$50 \% \mathrm{H}_{2} \mathrm{O}$ and $50 \% \mathrm{MeOH}$ to $100 \% \mathrm{MeOH}$ with $0.1 \%$ formic acid over $15 \mathrm{~min}$. ${ }^{1} \mathrm{H} \mathrm{NMR}\left(500 \mathrm{MHz} ; \mathrm{CDCl}_{3}\right)$ : $\delta 7.38(\mathrm{t}, J=4.2 \mathrm{~Hz}, 5 \mathrm{H}), 7.13(\mathrm{~d}, J=8.5 \mathrm{~Hz}, 1 \mathrm{H}), 6.65(\mathrm{dd}, J=8.4,2.7 \mathrm{~Hz}, 1 \mathrm{H}), 6.57(\mathrm{~d}, J=2.6 \mathrm{~Hz}, 1 \mathrm{H})$, $6.01(\mathrm{~s}(\mathrm{br}), 1 \mathrm{H}), 4.80(\mathrm{~s}, 2 \mathrm{H}), 3.75(\mathrm{td}, J=8.2,4.7 \mathrm{~Hz}, 1 \mathrm{H}), 3.66(\mathrm{~s}, 2 \mathrm{H}), 2.85(\mathrm{dd}, J=16.8,5.2 \mathrm{~Hz}, 1 \mathrm{H})$, $2.71(\mathrm{~d}, J=16.3 \mathrm{~Hz}, 1 \mathrm{H}), 2.39(\mathrm{t}, J=7.2 \mathrm{~Hz}, 2 \mathrm{H}), 2.34-2.27(\mathrm{~m}, 2 \mathrm{H}), 2.16-2.09(\mathrm{~m}, 1 \mathrm{H}), 1.92-1.89(\mathrm{~m}, 1 \mathrm{H})$, 1.74-1.11 (m, 28H), $0.91(\mathrm{t}, J=7.4 \mathrm{~Hz}, 3 \mathrm{H}), 0.78(\mathrm{~s}, 3 \mathrm{H}) .{ }^{13} \mathrm{C} \mathrm{NMR}\left(126 \mathrm{MHz} ; \mathrm{CDCl}_{3}\right): \delta 167.7,154.0$, 137.1, 134.7, 131.5, 129.21, 129.05, 128.85, 127.1, 116.3, 113.1, 82.2, 76.4, 46.6, 43.5, 42.2, 38.3, 37.1, 34.8, $33.4,30.7,29.64,29.54,29.48,29.41,29.32,27.9,27.4,25.4,24.8,22.8,20.1,13.9,11.3 \mathrm{HRMS}$ (APCI) m/z calcd for $\left[(\mathrm{M}+\mathrm{H})^{+}\right]=618.4522$, found $=618.4507$

$N$-butyl-11-((7R,8R,9S,13S,14S,17S)-3,17-dihydroxy-13-methyl-7,8,9,11,12,13,14,15,16,17decahydro- $6 H$-cyclopenta $[a]$ phenanthren-7-yl)- $N$-hydroxyundecanamide (22): Palladium on carbon ( $10 \% \mathrm{w} / \mathrm{w}, 13 \mathrm{mg}, 0.012 \mathrm{mmol}, 0.4$ equiv.) was added to a solution of 21 (20 mg, $0.03 \mathrm{mmol}, 1.0$ equiv.) in ethanol $(2.0 \mathrm{~mL})$, and was stirred at r.t. for $45 \mathrm{~min}$ under a hydrogen atmosphere. The reaction mixture was filtered through celite and concentrated. The residue was purified by chromatography on octadecylfunctionalized silica gel eluting a gradient of $50 \%$ to $100 \%$ methanol in water giving 22 as a colourless oil (12 mg, 70\%). ${ }^{1} \mathrm{H}$ NMR (400 MHz; CD $\left.3 \mathrm{OD}\right): \delta 7.08(\mathrm{~d}, J=8.5 \mathrm{~Hz}, 1 \mathrm{H}), 6.54(\mathrm{dd}, J=8.4,2.5 \mathrm{~Hz}, 1 \mathrm{H}), 6.46$ $(\mathrm{d}, J=2.2 \mathrm{~Hz}, 1 \mathrm{H}), 3.67(\mathrm{t}, J=8.5 \mathrm{~Hz}, 1 \mathrm{H}), 3.59(\mathrm{t}, J=7.0 \mathrm{~Hz}, 2 \mathrm{H}), 2.84-2.79(\mathrm{~m}, 1 \mathrm{H}), 2.69(\mathrm{dd}, J=16.6$, $0.4 \mathrm{~Hz}, 1 \mathrm{H}), 2.44(\mathrm{t}, J=7.5 \mathrm{~Hz}, 2 \mathrm{H}), 2.35-2.25(\mathrm{~m}, 2 \mathrm{H}), 2.06-1.89(\mathrm{~m}, 3 \mathrm{H}), 1.76-1.15(\mathrm{~m}, 34 \mathrm{H}), 0.98-0.90$ $(\mathrm{m}, 3 \mathrm{H}), 0.78(\mathrm{~s}, 3 \mathrm{H}) .{ }^{13} \mathrm{C}$ NMR $\left(126 \mathrm{MHz} ; \mathrm{CDCl}_{3}\right): \delta 166.6,148.7,137.4,129.30,129.07,129.07,128.9$, 127.2 , 122.58, 118.9, 83.0, 46.5, 43.1, 41.6, 38.3, 37.3, 34.7, 33.3, 30.2, 30.0, 29.85, 29.65, 28.4, 27.75, 27.19, 25.9, 24.9, 23.0, 21.4, 14.0, 11.2. HRMS (ESI) $\mathrm{m} / \mathrm{z}$ calcd for $\left[(\mathrm{M}+\mathrm{H})^{+}\right]=550.3872$, found $=550.3871$

3-amino- $\boldsymbol{N}$-(benzyloxy)- $\boldsymbol{N}$-butylbenzamide (25): HBTU (3.2 g, $8.37 \mathrm{mmol}, 1.6$ equiv.) was added at r.t. in one portion to a solution of carboxylic acid 24 (715 $\mathrm{mg}, 5.21 \mathrm{mmol}, 1.0$ equiv.), O-benzyl-hydroxylamine (1.4 g, $7.82 \mathrm{mmol}, 1.5$ equiv.) and DIPEA (4.5 mL, $26.05 \mathrm{mmol}, 5.0$ equiv.) in dry DMF (10 mL) under an argon atmosphere. The reaction was stirred for $2 \mathrm{~h}$ at r.t. and was quenched with brine $(5 \times$ the reaction volume). The reaction was extracted with ethyl acetate $(2 \times)$ and the combined organic layers were washed with water $(4 \times)$, aqueous $0.1 \mathrm{M} \mathrm{HCl}$, saturated solution of ammonium chloride and brine. The organic layer was dried over anhydrous sodium sulfate, filtered and concentrated. The residue was purified by chromatography on silica gel eluting $25 \%$ ethyl acetate in toluene to give $\mathbf{2 5}$ as a solid $(1.35 \mathrm{~g}, 87 \%)$. ${ }^{1} \mathrm{H}$ NMR (400 MHz; $\left.\mathrm{CDCl}_{3}\right): \delta$ 7.32-7.28 (m, 3H), 7.18-7.14 (m, 3H), $6.99(\mathrm{~d}, J=7.6 \mathrm{~Hz}, 1 \mathrm{H}), 6.91(\mathrm{t}, J=1.8$ $\mathrm{Hz}, 1 \mathrm{H}), 6.76(\mathrm{ddd}, J=8.0,2.4,1.0 \mathrm{~Hz}, 1 \mathrm{H}), 4.69(\mathrm{~s}, 2 \mathrm{H}), 3.69(\mathrm{~m}, 4 \mathrm{H}), 1.73-1.65(\mathrm{~m}, 3 \mathrm{H}), 1.36(\mathrm{dd}, J=$ $15.0,7.5 \mathrm{~Hz}, 2 \mathrm{H}), 0.91(\mathrm{t}, J=7.4 \mathrm{~Hz}, 3 \mathrm{H}) .{ }^{13} \mathrm{C} \mathrm{NMR}\left(101 \mathrm{MHz} ; \mathrm{CDCl}_{3}\right): \delta 170.3,146.3,135.9,129.6,129.0$, $128.8,128.6,118.3,117.0,114.7,76.5,29.5,20.0,13.9$. IR (thin film) 3347, 2006, 2970, 1738, 1366, 764 HRMS $(\mathrm{ESI}) \mathrm{m} / \mathrm{z}$ calcd for $\left[(\mathrm{M}+\mathrm{Na})^{+}\right]=321.1579$, found $=321.1579$

$\boldsymbol{N}$-(benzyloxy)-3-(6-bromohexanamido)- $\boldsymbol{N}$-butylbenzamide (26): $\mathrm{EDC} \cdot \mathrm{HCl}(475 \mathrm{mg}, 2.48 \mathrm{mmol}, 1.5$ equiv.) was added to a solution of 6-bromohexanoic acid (386 mg, $1.98 \mathrm{mmol}, 1.2$ equiv.), aniline 25 (491 $\mathrm{mg}, 1.65 \mathrm{mmol}, 1.0$ equiv.) and DMAP (80 mg, $0.66 \mathrm{mmol}, 0.4$ equiv.) in dry DCM $(10 \mathrm{~mL})$ at $0^{\circ} \mathrm{C}$. Upon addition, the cold bath was removed and the reaction mixture was stirred for $4 \mathrm{~h}$ at r.t.. Upon completion, the reaction mixture was quenched with water. The reaction was extracted with ethyl acetate $(2 \times)$ and the combined organic fractions were washed with $0.1 \mathrm{M} \mathrm{HCl}$, water and brine. The organic layer was dried over sodium sulfate, filtered and concentrated.The resulting residue was purified by chromatography on silica gel eluting $15-25 \%$ ethyl acetate in toluene to obtain $\mathbf{2 6}$ as a viscous oil $\left(636 \mathrm{mg}, 81 \%\right.$ yield). ${ }^{1} \mathrm{H}$ NMR (400 MHz; $\left.\mathrm{CDCl}_{3}\right): \delta 8.05(\mathrm{~s}, 1 \mathrm{H}), 7.94(\mathrm{~d}, J=6.4 \mathrm{~Hz}, 1 \mathrm{H}), 7.53(\mathrm{~s}, 1 \mathrm{H}), 7.30$ (sextet, $\left.J=5.8 \mathrm{~Hz}, 5 \mathrm{H}\right), 7.10(\mathrm{~s}$, $2 \mathrm{H}), 4.68(\mathrm{~s}, 2 \mathrm{H}), 3.72(\mathrm{~s}, 2 \mathrm{H}), 3.40(\mathrm{t}, J=6.7 \mathrm{~Hz}, 2 \mathrm{H}), 2.35(\mathrm{t}, J=7.4 \mathrm{~Hz}, 2 \mathrm{H}), 1.88$ (quintet, $J=7.2 \mathrm{~Hz}$, $2 \mathrm{H}), 1.76-1.67(\mathrm{~m}, 4 \mathrm{H}), 1.49(\mathrm{dt}, J=15.3,7.6 \mathrm{~Hz}, 2 \mathrm{H}), 1.36(\mathrm{dq}, J=14.8,7.4 \mathrm{~Hz}, 2 \mathrm{H}), 0.92(\mathrm{t}, J=7.3 \mathrm{~Hz}$, $3 \mathrm{H}) .{ }^{13} \mathrm{C}$ NMR $\left(75 \mathrm{MHz} ; \mathrm{CDCl}_{3}\right): \delta 171.4,169.7,138.2,135.0,134.1,129.4,128.81,128.68,128.50,123.4$, 122.0, 119.3, 77.5, 77.0, 76.61, 76.48, 37.2, 33.61, 33.46, 32.45, 32.36, 29.3, 27.7, 24.6, 19.9. IR (thin film) $3276,2930,1763,1705,1656,1275,1043,738$. HRMS $(\mathrm{ESI}) \mathrm{m} / \mathrm{z}$ calcd for $\left[(\mathrm{M}+\mathrm{Na})^{+}\right]=497.1416$, found $=$ 497.1415 
$N$-butyl-3-(6-(( $7 R, 8 R, 9 S, 13 S, 14 S, 17 S)-3,17-d i h y d r o x y-13-m e t h y l-7,8,9,11,12,13,14,15,16,17-$ decahydro- $6 \boldsymbol{H}$-cyclopenta[a]phenanthren-7-yl)thio)hexanamido)- $\boldsymbol{N}$-hydroxybenzamide (27): $\mathrm{K}_{2} \mathrm{CO}_{3}$ (261 mg, $1.89 \mathrm{mmol}, 6.0$ equiv.) was added to a mixture of thiol 23 (100 mg, $0.315 \mathrm{mmol}, 1.0$ equiv.) and, alkyl bromide 26 (600 mg, $1.26 \mathrm{mmol}, 4.0$ equiv.) in degassed acetonitrile (10.0 mL) at r.t. under argon atmosphere and stirred for $12 \mathrm{~h}$ at r.t.. The reaction was monitored via TLC and upon reaction completion, the reaction mixture was quenched with $0.1 \mathrm{M} \mathrm{HCl}$ until reaching $\mathrm{pH} 3-5$ and the organic solvent was concentrated under vacuum. The resulting residue was dissolved in ethyl acetate. $\mathrm{NaCl}$ was added to the mixture until reaching saturation of the aqueous phase and the resulting mixture was extracted with ethyl acetate $(2 \times)$. The combined organic extracts were dried over anhydrous sodium sulfate, filtered and concentrated. The resulting residue was purified by chromatography on octadecyl-functionalized silica gel eluting $25-85 \%$ methanol in water. The resulting thioether was dissolved in a 1:1 mixture of ethanol/ethyl acetate $(5 \mathrm{~mL})$ and palladium on carbon $(10 \% \mathrm{w} / \mathrm{w}, 33 \mathrm{mg}, 0.063 \mathrm{mmol}, 0.1$ equiv.) was to solution and was stirred at r.t. for $25 \mathrm{~min}$. The reaction mixture was then filtered through Celite and concentrated under vacuum. The residue was purified by chromatography on octadecyl-functionalized silica gel eluting a gradient of 50\% to $100 \%$ methanol in water giving 27 as an oil (67 mg, 35\% yield). Purity by HPLC: 99\%, $\mathrm{t}_{\mathrm{r}}=4.75$, conditions: linear gradient from $50 \% \mathrm{H}_{2} \mathrm{O}$ and $50 \% \mathrm{MeOH}$ to $100 \% \mathrm{MeOH}$ with $0.1 \%$ formic acid over $15 \mathrm{~min} .{ }^{1} \mathrm{H}$ NMR (400 MHz; $\left.\mathrm{CD}_{3} \mathrm{OD}\right): \delta 7.84(\mathrm{~s}, 1 \mathrm{H}), 7.63(\mathrm{~d}, J=7.1 \mathrm{~Hz}, 1 \mathrm{H}), 7.37(\mathrm{t}, J=7.9 \mathrm{~Hz}$, $1 \mathrm{H}), 7.30(\mathrm{~s}, 1 \mathrm{H}), 7.08(\mathrm{~d}, J=8.4 \mathrm{~Hz}, 1 \mathrm{H}), 6.56(\mathrm{dd}, J=8.4,2.5 \mathrm{~Hz}, 1 \mathrm{H}), 6.47(\mathrm{~d}, J=2.3 \mathrm{~Hz}, 1 \mathrm{H}), 3.69(\mathrm{~s}$, $1 \mathrm{H}), 3.64(\mathrm{t}, J=8.5 \mathrm{~Hz}, 1 \mathrm{H}), 3.13(\mathrm{~m}, 2 \mathrm{H}), 2.96(\mathrm{~d}, J=17.0 \mathrm{~Hz}, 1 \mathrm{H}), 2.57(\mathrm{dq}, J=11.9,6.1 \mathrm{~Hz}, 2 \mathrm{H}), 2.43-$ $2.29(\mathrm{~m}, 4 \mathrm{H}), 2.03(\mathrm{dtd}, J=13.5,8.8,5.0 \mathrm{~Hz}, 1 \mathrm{H}), 1.92-1.88(\mathrm{~m}, 1 \mathrm{H}), 1.77-1.19(\mathrm{~m}, 16 \mathrm{H}), 0.99-0.90(\mathrm{~m}$, $3 \mathrm{H}), 0.76(\mathrm{~s}, 3 \mathrm{H}) .{ }^{13} \mathrm{C}$ NMR $\left(126 \mathrm{MHz} ; \mathrm{CD}_{3} \mathrm{OD}\right): \delta 174.8,171.9,156.2,140.1,136.60,136.51,131.7,129.8$, $127.8,124.5,123.0,120.6,116.9,114.3,82.5,51.2,48.1,44.7,44.4,44.2,40.1,38.4,38.06,37.97,31.9$, $30.88,30.73,30.4,29.6,28.3,26.5,23.6,21.0,14.2,11.9$. IR (thin film) $3274,3013,29830,1735,1708$, $1656,1275,1259,764$. HRMS (ESI) $\mathrm{m} / \mathrm{z}$ calcd for $\left[(\mathrm{M}+\mathrm{Na})^{+}\right]=631.3182$, found $=631.3165$

\section{Biological protocols}

\section{Cell lines, reagents and plasmids}

Cell lines were ordered from ATCC. SAHA were purchased from Tocris Cookson Ltd (Minneapolis, MN). ER $\alpha$-Rluc was cloned as previously descried. ${ }^{36}$ LXXLL-eYFP was generated by cloning of SRC2 residues 690 to 694 into the peYFP-N1 vector described in Breton et al ${ }^{43}$.

\section{Cell transfection and BRET assays}

HEK293 cells were grown to confluence, trypsinized and plated at a density of 0.5 million cells per well (12-well plates) in DMEM supplemented with 10\% charcoal-treated FBS (FBS-T). The following day, cells were transfected with PEI using $0.1 \mu \mathrm{g}$ of ER $\alpha$-RLuc vector and $1 \mu \mathrm{g}$ of NCoA1-eYFP vector. $48 \mathrm{~h}$ posttransfection, cells were co-treated with hybrid compounds and E2 $(1 \mathrm{nM})$ for $2 \mathrm{~h}$ before taking BRET measurements. Luminescence was measured using a TriStar LB 941 (berthold Technology, Bad Wildbad, Germany) with detection channels centered on 485 and $530 \mathrm{~nm}$ for Donor and Acceptor emissions, respectively. $\mathrm{IC}_{50}$ s were calculated using GraphPad $\left(\mathrm{R}^{2}\right.$ values all above .96$)$ from 3 experiments and standard error is less than $2.5 \%$.

\section{Luciferase assay}

T47D-KBLuc cells (ATCC) were maintained in phenol red-free RPMI medium (10\% dextran-charcoal treated FBS, $2.5 \mathrm{~g} / \mathrm{L}$ D-glucose, $10 \mathrm{mM}$ HEPES, $1 \mathrm{mM}$ sodium pyruvate, $2 \%$ L-glutamine, 1\% Pen/Strep) for $72 \mathrm{~h}$. Cells were seeded at a density of 10000 cells per well in 96-well white luminescence plates in triplicates (BD Falcon). The following day, medium was changed for medium containing antiestrogens, HDACis or hybrid molecules in combination with E2 $(0.1 \mathrm{nM})$ or an equal volume of DMSO. For the calculation of $\mathrm{IC}_{50}$ values, molecules were tested starting with a maximum of $5 \mu \mathrm{M}$ (hybrids) or $2 \mu \mathrm{M}(\mathrm{OHT})$, and 1:2 dilutions thereafter across twelve concentrations. Cells were incubated for $24 \mathrm{~h}$ at $37^{\circ} \mathrm{C}$. Cells were washed once with PBS, and lysis buffer containing $705 \mu \mathrm{M}$ D-luciferin (Nanolight Technologies) was added. 
Plates were read on a luminescence counter following 8 minutes of incubation at r.t.. Each experiment was performed 2-3 times.

\section{HDACi assay}

Boc-Lys(Ac)-7-amino-4-methylcoumarin (Boc-Lys(Ac)-AMC) was used as substrate for the HDAC assays. Substrate solution was prepared as follows: Boc-Lys(Ac)-AMC was dissolved in DMSO and diluted with HDAC buffer (15 mM Tris- $\mathrm{HCl}$ [pH 8.1], $250 \mu \mathrm{M}$ EDTA, $250 \mathrm{mM} \mathrm{NaCl}, 10 \%$ glycerol) to give $1 \mathrm{mM}$ solutions containing 1.7\% DMSO. HDAC enzyme solutions were prepared by diluting HDAC3 and HDAC6 (Cayman Chemical) to concentrations of $0.02 \mathrm{ng} / \mu \mathrm{L}$ and $0.05 \mathrm{ng} / \mu \mathrm{L}$ in HDAC buffer (above). A trypsin solution $(10 \mathrm{mg} / \mathrm{mL})$ in HDAC buffer was used for development. Release of AMC was monitored by measuring the fluorescence at $460 \mathrm{~nm}\left(\lambda_{\mathrm{ex}}=390 \mathrm{~nm}\right)$ with a microplate reader (SpectraMax Gemini) at 37 ${ }^{\circ} \mathrm{C}$. The AMC signals were recorded against a blank with buffer, substrate and trypsin but without the enzyme. All experiments were carried out at least in triplicate.

For HDAC assays, inhibitor (or none for control) diluted in $50 \mu \mathrm{L}$ of HDAC buffer was mixed with $10 \mu \mathrm{L}$ of diluted HDAC2, -3 or -6 solution in HDAC buffer at r.t.. The assay was begun by adding $40 \mu \mathrm{L}$ of substrate solution in HDAC buffer followed by incubation with stirring at $37{ }^{\circ} \mathrm{C}$. After $30 \mathrm{~min}, 100 \mu \mathrm{L}$ of trypsin solution was added. After a further 10 min incubation period with stirring at $37^{\circ} \mathrm{C}$, the release of $\mathrm{AMC}$ was monitored by measuring the fluorescence.

\section{Cell growth measurement}

Cell were plated at 0.4 million cells per well (6-well plate) in DMEM 5\% FBS-T for all cell lines. Cells were treated every $48 \mathrm{~h}$ and media was refreshed every $96 \mathrm{~h}$. After 10 days of treatment, cells were harvested in $0.1 \mathrm{~N} \mathrm{NaOH}$ and growth was quantified by analyzing protein content of lysates with a Lowry assay.

\section{Acknowledgments}

This work was funded by grants from the Le Fonds de recherche du Québec - Nature et technologies, the Quebec Breast Cancer Foundation and the Canadian Institutes of Health Research to JLG and SM. RMS thanks Consejo Nacional de Ciencia y Tecnología (Mexico) and CIHR for postgraduate fellowships. JP thanks CIHR for a postgraduate fellowship.

\section{References}

1. http://www.cancer.org/research/cancerfactsstatistics/cancerfactsfigures2015/index.

2. Nilsson, S.; Gustafsson, J. A., Crit. Rev. Biochem. Mol. Biol. 2002, 37, 1-28.

3. Sanchez, R.; Nguyen, D.; Rocha, W.; White, J. H.; Mader, S., Bioessays 2002, 24, 244-254.

4. Ricketts, D.; Turnbull, L.; Ryall, G.; Bakhshi, R.; Rawson, N. S.; Gazet, J. C.; Nolan, C.; Coombes, R. C., Cancer Res. 1991, 51, 1817-1822.

5. (a) Ariazi, E. A.; Ariazi, J. L.; Cordera, F.; Jordan, V. C., Curr. Top. Med. Chem. 2006, 6, 181-202; (b) Jordan, V. C.; O'Malley, B. W., J. Clin. Oncol. 2007, 25, 5815-5824.

6. Miller, C. P., Curr. Pharm. Des. 2002, 8, 2089-2111.

7. (a) Cole, M. P.; Jones, C. T.; Todd, I. D., Br. J. Cancer 1971, 25, 270-5; (b) Ward, H. W., Br. Med. J. 1973, $1,13-14$.

8. Muchmore, D. B., Oncologist 2000, 5, 388-392.

9. (a) Wakeling, A. E.; Bowler, J., J. Ster. Biochem. 1988, 30, 141-147; (b) Wakeling, A. E.; Bowler, J., J. Endocrinol. 1987, 112, R7-10.

10. Howell, A.; Osborne, C. K.; Morris, C.; Wakeling, A. E., Cancer 2000, 89, 817-825.

11. Agnusdei, D.; Iori, N., Curr. Med. Chem. 2000, 7, 577-584. 
12. Jordan, N. J.; Gee, J. M.; Barrow, D.; Wakeling, A. E.; Nicholson, R. I., Breast Cancer Res. Treat. 2004, 87, 167-180.

13. (a) Bowler, J.; Lilley, T. J.; Pittam, J. D.; Wakeling, A. E., Steroids 1989, 54, 71-99; (b) Wijayaratne, A. L.; McDonnell, D. P., J. Biol. Chem. 2001, 276, 35684-35692; (c) Hilmi, K.; Hussein, N.; MendozaSanchez, R.; El-Ezzy, M.; Ismail, H.; Durette, C.; Bail, M.; Rozendaal, M. J.; Bouvier, M.; Thibault, P.; Gleason, J. L.; Mader, S., Mol. Cell. Biol. 2012, 32, 3823-3837.

14. (a) Lancet 1998, 351, 1451-67; (b) Lee, W. L.; Cheng, M. H.; Chao, H. T.; Wang, P. H., Taiwan J. Obstet. Gynecol. 2008, 47, 24-31.

15. Chia, S.; Gradishar, W.; Mauriac, L.; Bines, J.; Amant, F.; Federico, M.; Fein, L.; Romieu, G.; Buzdar, A.; Robertson, J. F.; Brufsky, A.; Possinger, K.; Rennie, P.; Sapunar, F.; Lowe, E.; Piccart, M., J. Clin. Oncol. 2008, 26, 1664-1670.

16. de Ruijter, A. J.; van Gennip, A. H.; Caron, H. N.; Kemp, S.; van Kuilenburg, A. B., Biochem. J. 2003, 370, 737-749.

17. (a) Struhl, K., Genes Dev. 1998, 12, 599-606; (b) Jovanovic, J.; Ronneberg, J. A.; Tost, J.; Kristensen, V., Mol. Oncol. 2010, 4, 242-254.

18. Bertrand, P., Eur J Med Chem 2010, 45, 2095-2116.

19. (a) Khan, O.; La Thangue, N. B., Immunol. Cell. Biol. 2012, 90, 85-94; (b) Haberland, M.; Montgomery, R. L.; Olson, E. N., Nat. Rev. Genet. 2009, 10, 32-42.

20. (a) Mann, B. S.; Johnson, J. R.; He, K.; Sridhara, R.; Abraham, S.; Booth, B. P.; Verbois, L.; Morse, D. E.; Jee, J. M.; Pope, S.; Harapanhalli, R. S.; Dagher, R.; Farrell, A.; Justice, R.; Pazdur, R., Clin. Cancer Res. 2007, 13, 2318-2322; (b) Prince, H. M.; Dickinson, M., Clin. Cancer Res. 2012, 18, 3509-3515; (c) Dokmanovic, M.; Clarke, C.; Marks, P. A., Mol. Cancer Res. 2007, 5, 981-989.

21. Thurn, K. T.; Thomas, S.; Moore, A.; Münster, P. N., Future Oncology 2011, 7, 263-283.

22. (a) Linares, A.; Dalenc, F.; Balaguer, P.; Boulle, N.; Cavailles, V., J. Biomed. Biotech. 2011, 2011, 856985; (b) Hodges-Gallagher, L.; Valentine, C. D.; Bader, S. E.; Kushner, P. J., Breast Cancer Res. Treat. 2007, 105, 297-309; (c) Tu, Z.; Li, H.; Ma, Y.; Tang, B.; Tian, J.; Akers, W.; Achilefu, S.; Gu, Y., Mol. Cell. Biochem. 2012, 366, 111-122.

23. De los Santos, M.; Martinez-Iglesias, O.; Aranda, A., Endocrine Related Cancer 2007, 14, 1021-1028.

24. Munster, P. N.; Thurn, K. T.; Thomas, S.; Raha, P.; Lacevic, M.; Miller, A.; Melisko, M.; Ismail-Khan, R.; Rugo, H.; Moasser, M.; Minton, S. E., Br. J. Cancer 2011, 104, 1828-1835.

25. Zimmermann, G. R.; Lehár, J.; Keith, C. T., Drug Disc. Tod. 2007, 12, 34-42.

26. (a) Morphy, R., Drug Disc. Tod. 2004, 9, 641-651; (b) Costantino, L.; Barlocco, D., Curr. Med. Chem. 2012, 19, 3353-3387; (c) Geldenhuys, W. J.; Youdim, M.; Carroll, R. T., Prog. Neurobiol. 2011, 94, 347-359; (d) Trstenjak, U.; Kikelj, D., Curr. Med. Chem. 2011, 18, 2531-2542; (e) M O'Boyle, N.; J Meegan, M., Curr. Med. Chem. 2011, 18, 4722-4737.

27. Tavera-Mendoza, L. E.; Quach, T. D.; Dabbas, B.; Hudon, J.; Liao, X.; Palijan, A.; Gleason, J. L.; White, J. H., Proc. Nat. Acad. Sci. 2008, 105, 8250-8255.

28. (a) Lamblin, M.; Spingarn, R.; Wang, T.-T.; Burger, M. C.; Dabbas, B.; Moitessier, N.; White, J. H.; Gleason, J. L., J. Med. Chem. 2010, 53, 7461-7465; (b) Lamblin, M.; Dabbas, B.; Spingarn, R.; Mendoza-Sanchez, R.; Wang, T.-T.; An, B.-S.; Huang, D. C.; Kremer, R.; White, J. H.; Gleason, J. L., Bioorg. Med. Chem. 2010, 18, 4119-4137; (c) Fischer, J.; Wang, T.-T.; Kaldre, D.; Rochel, N.; Moras, D.; White, J. H.; Gleason, J. L., Chem. Biol. 2012, 19, 963-971; (d) Kaldre, D.; Wang, T. T.; Fischer, J.; White, J. H.; Gleason, J. L., Bioorg. Med. Chem. 2015, 23, 5035-5049. 
29. (a) Lai, C. J.; Bao, R.; Tao, X.; Wang, J.; Atoyan, R.; Qu, H.; Wang, D. G.; Yin, L.; Samson, M.; Forrester, J.; Zifcak, B.; Xu, G. X.; DellaRocca, S.; Zhai, H. X.; Cai, X.; Munger, W. E.; Keegan, M.; Pepicelli, C. V.; Qian, C., Cancer Res. 2010, 70, 3647-3656; (b) Chen, L.; Wilson, D.; Jayaram, H. N.; Pankiewicz, K. W., J. Med. Chem. 2007, 50, 6685-6691; (c) Chen, L.; Petrelli, R.; Gao, G.; Wilson, D. J.; McLean, G. T.; Jayaram, H. N.; Sham, Y. Y.; Pankiewicz, K. W., Biorg. Med. Chem. 2010, 18, 59505964; (d) Griffith, D.; Morgan, M. P.; Marmion, C. J., Chem. Commun. 2009, 0, 6735-6737; (e) Beckers, T.; Mahboobi, S.; Sellmer, A.; Winkler, M.; Eichhorn, E.; Pongratz, H.; Maier, T.; Ciossek, T.; Baer, T.; Kelter, G.; Fiebig, H.-H.; Schmidt, M., MedChemComm 2012, 3, 829-835; (f) Mahboobi, S.; Dove, S.; Sellmer, A.; Winkler, M.; Eichhorn, E.; Pongratz, H.; Ciossek, T.; Baer, T.; Maier, T.; Beckers, T., J. Med. Chem. 2009, 52, 2265-2279; (g) Guerrant, W.; Patil, V.; Canzoneri, J. C.; Oyelere, A. K., J. Med. Chem. 2012, 55, 1465-1477; (h) Ko, K. S.; Steffey, M. E.; Brandvold, K. R.; Soellner, M. B., Med. Chem. Lett. 2013, 4, 779-783; (i) Qian, C.; Lai, C. J.; Bao, R.; Wang, D. G.; Wang, J.; Xu, G. X.; Atoyan, R.; Qu, H.; Yin, L.; Samson, M.; Zifcak, B.; Ma, A. W. S.; DellaRocca, S.; Borek, M.; Zhai, H. X.; Cai, X.; Voi, M., Clin. Cancer Res. 2012, 18, 4104-4113.

30. (a) Tang, C.; Li, C.; Zhang, S.; Hu, Z.; Wu, J.; Dong, C.; Huang, J.; Zhou, H.-B., J. Med. Chem. 2015, 58, 4550-4572; (b) Patel, H. K.; Siklos, M. I.; Abdelkarim, H.; Mendonca, E. L.; Vaidya, A.; Petukhov, P. A.; Thatcher, G. R. J., ChemMedChem 2013 9, 602-613(c) Gryder, B. E.; Rood, M. K.; Johnson, K. A.; Patil, V.; Raftery, E. D.; Yao, L.-P. D.; Rice, M.; Azizi, B.; Doyle, D.; Oyelere, A. K., J. Med. Chem. 2013, 56, 5782-5796.

31. Pike, A. C.; Brzozowski, A. M.; Walton, J.; Hubbard, R. E.; Thorsell, A. G.; Li, Y. L.; Gustafsson, J. A.; Carlquist, M., Structure (Camb) 2001, 9, 145-153.

32. (a) Marson, C. M., Anticancer Agents Med. Chem. 2009, 9, 661-692; (b) Vadivelan, S.; Sinha, B. N.; Rambabu, G.; Boppana, K.; Jagarlapudi, S. A. R. P., J. Mol. Graph. Mod. 2008, 26, 935-946; (c) Yoshida, M.; Matsuyama, A.; Komatsu, Y.; Nishino, N., Curr. Med. Chem. 2003, 10, 2351-2358.

33. Jiang, X.-R.; Walter Sowell, J.; Zhu, B. T., Steroids 2006, 71, 334-342.

34. (a) Spera, D.; Cabrera, G.; Fiaschi, R.; Carlson, K. E.; Katzenellenbogen, J. A.; Napolitano, E., Bioorg. Med. Chem. 2004, 12, 4393-4401; (b) Miller, C. P.; Jirkovsky, I.; Tran, B. D.; Harris, H. A.; Moran, R. A.; Komm, B. S., Bioorg. Med. Chem. Lett. 2000, 10, 147-151.

35. Hamdan, F. F.; Percherancier, Y.; Breton, B.; Bouvier, M., Current protocols in neuroscienc 2006, Chapter 5, Unit 523.

36. Lupien, M.; Jeyakumar, M.; Hebert, E.; Hilmi, K.; Cotnoir-White, D.; Loch, C.; Auger, A.; Dayan, G.; Pinard, G. A.; Wurtz, J. M.; Moras, D.; Katzenellenbogen, J.; Mader, S., Mol Endocrinol 2007, 21, 797816.

37. (a) Castro-Rivera, E.; Safe, S., J. Steroid Biochem. Mol. Biol. 2003, 84, 23-31; (b) Fan, J. D.; Wagner, B. L.; McDonnell, D. P., Mol Endocrinol 1996, 10, 1605-1616; (c) Norris, J. D.; Fan, D.; Stallcup, M. R.; McDonnell, D. P., J. Biol. Chem. 1998, 273, 6679-6688.

38. Wegener, D.; Wirsching, F.; Riester, D.; Schwienhorst, A., Chem. Biol. 2003, 10, 61-68.

39. (a) Bradner, J. E.; West, N.; Grachan, M. L.; Greenberg, E. F.; Haggarty, S. J.; Warnow, T.; Mazitschek, R., Nat. Chem. Biol. 2010, 6, 238-243; (b) Khan, N.; Jeffers, M.; Kumar, S.; Hackett, C.; Boldog, F.; Khramtsov, N.; Qian, X.; Mills, E.; Berghs, S. C.; Carey, N.; Finn, P. W.; Collins, L. S.; Tumber, A.; Ritchie, J. W.; Jensen, P. B.; Lichenstein, H. S.; Sehested, M., Biochem. J. 2008, 409, 581-589.

40. Pottel, J.; Therrien, E.; Gleason, J. L.; Moitessier, N., J. Chem. Info. Model. 2014, 54, 254-265.

41. Wang, D.-F.; Helquist, P.; Wiech, N. L.; Wiest, O., J. Med. Chem. 2005, 48, 6936-6947. 
42. Lauffer, B. E. L.; Mintzer, R.; Fong, R.; Mukund, S.; Tam, C.; Zilberleyb, I.; Flicke, B.; Ritscher, A.; Fedorowicz, G.; Vallero, R.; Ortwine, D. F.; Gunzner, J.; Modrusan, Z.; Neumann, L.; Koth, C. M.; Lupardus, P. J.; Kaminker, J. S.; Heise, C. E.; Steiner, P., J. Biol. Chem. 2013, 288, 26926-26943.

43. Breton, B.; Sauvageau, E.; Zhou, J.; Bonin, H.; Le Gouill, C.; Bouvier, M., Biophys. J. 2010, 99, $4037-$ 4046. 